Open Access

\title{
Acute and subchronic exposure to air particulate matter induces expression of angiotensin and bradykinin-related genes in the lungs and heart: Angiotensin-II type-I receptor as a molecular target of particulate matter exposure
}

Octavio Gamaliel Aztatzi-Aguilar ${ }^{1}$, Marisela Uribe-Ramírez , José Antonio Arias-Montaño², Olivier Barbier ${ }^{1}$ and Andrea De Vizcaya-Ruiz ${ }^{1 *}$

\begin{abstract}
Background: Particulate matter (PM) adverse effects on health include lung and heart damage. The renin-angiotensin-aldosterone (RAAS) and kallikrein-kinin (KKS) endocrine systems are involved in the pathophysiology of cardiovascular diseases and have been found to impact lung diseases. The aim of the present study was to evaluate whether PM exposure regulates elements of RAAS and KKS.

Methods: Sprague-Dawley rats were acutely (3 days) and subchronically (8 weeks) exposed to coarse (CP), fine (FP) or ultrafine (UFP) particulates using a particulate concentrator, and a control group exposed to filtered air (FA). We evaluated the mRNA of the RAAS components At1, At2r and Ace, and of the KKS components B1r, B2r and $K I k-1$ by RT-PCR in the lungs and heart. The ACE and $A T_{1} R$ protein were evaluated by Western blot, as were HO-1 and $\gamma$ GCSC as indicators of the antioxidant response and IL-6 levels as an inflammation marker.

We performed a binding assay to determinate $A T_{1} R$ density in the lung, also the subcellular AT $R$ distribution in the lungs was evaluated. Finally, we performed a histological analysis of intramyocardial coronary arteries and the expression of markers of heart gene reprogramming (Acta1 and Col3a1).

Results: The PM fractions induced the expression of RAAS and KKS elements in the lungs and heart in a time-dependent manner. CP exposure induced Ace mRNA expression and regulated its protein in the lungs. Acute and subchronic exposure

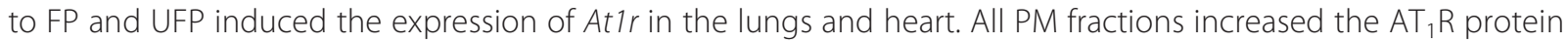
in a size-dependent manner in the lungs and heart after subchronic exposure. The $A T_{1} R$ lung protein showed a time-dependent change in subcellular distribution. In addition, the presence of $A T_{1} R$ in the heart was accompanied by a decrease in HO-1, which was concomitant with the induction of Actal and Col3al and the increment of IL-6. Moreover, exposure to all PM fractions increased coronary artery wall thickness.
\end{abstract}

Conclusion: We demonstrate that exposure to PM induces the expression of RAAS and KKS elements, including $\mathrm{AT}_{1} \mathrm{R}$, which was the main target in the lungs and the heart.

Keywords: Renin-angiotensin-aldosterone system, Kallikrein-kinin system, Particulate matter

\footnotetext{
* Correspondence: avizcaya@cinvestav.mx

'Departamento de Toxicología, Centro de Investigación y de Estudios

Avanzados del Instituto Politécnico Nacional, Avenida Instituto Politécnico

Nacional, 2508, México D. F., CP. 07360, Mexico

Full list of author information is available at the end of the article
} 


\section{Background}

Air quality has been associated with increases in the morbidity and mortality due not only to pulmonary diseases but also to cardiovascular diseases. While the first group of diseases can be explained by the fact that the respiratory system is the major route of exposure to air pollutants, the second group could be a consequence of intermediate steps that connect lung damage to cardiovascular alterations . Epidemiological studies indicate that particulate matter (PM) is involved in these diseases and that exposure to particulate less than $2.5 \mu \mathrm{m}$ is a major risk factor for the promotion and exacerbation of pulmonary and heart diseases [1-4].

The main mechanisms proposed to explain PM-induced toxic effects on human health are inflammation and oxidative stress. Recently, it has been demonstrated that the inflammatory response to PM promotes accelerated clotting with the participation of IL-6 cytokine [5]. Furthermore, oxidative stress can decrease heart rate variability after acute PM exposure [6]. Both mechanisms are involved in the pathophysiology of lung and heart diseases, i.e., COPD, asthma, fibrosis, hypertension, atherosclerosis, thrombosis, heart failure, etc., and are able to regulate or promote physiological responses including the activation of macrophages and neutrophils, regulation of the vascular tone, and production of mediators of signaling pathways, amongst others.

Important endocrine systems that regulate cardiovascular physiology are the Renin-Angiotensin-Aldosterone system (RAAS) and the Kallikrein-Kinin system (KKS).

Both systems are composed of peptidase enzymes [angiotensin-I converting enzyme type- 1 and -2 (ACE and ACE2, respectively) and tissue kallikrein (KLK-1)]; and receptors [angiotensin receptors type- 1 and type- $2\left(\mathrm{AT}_{1} \mathrm{R}\right.$ and $\mathrm{AT}_{2} \mathrm{R}$, respectively); and bradykinin receptors type- 1 and type- 2 $\left(B_{1} R\right.$ and $\left.B_{2} R\right)$ ]; and peptide precursors [angiotensinogen and kininogen (ANG and KNG, respectively)] [7-10]. Both systems control cardiac muscle contraction through vasoactive peptides, RAAS induces vasoconstriction through the $\mathrm{ACE} / \mathrm{Ang}-\mathrm{II} / \mathrm{AT}_{1} \mathrm{R}$ axis, but by itself, RAAS can induce vasodilatation by the stimulation of NO-bradykinin dependent release through ACE2/Ang-(1-7)/Mas receptor axis [11], which also, in cooperation with $B_{2} R, A_{2} R$ induces a vasodilatation effect. This effect orchestrated by $\mathrm{B}_{2} \mathrm{R}$, increases the release of $\mathrm{NO}$ through the activation of endothelial oxide nitric synthase (eNOS) $[8,12]$. Vascular dilatation has been reported to be dependent of KLK-1, $\mathrm{B}_{2} \mathrm{R}$ and $\mathrm{AT}_{2} \mathrm{R}$ [13], where KLK-1 has an important role in the generation of the vasodilator peptides (bradykinin and kallidin) [14, 15].

Moreover, angiotensin-II through the $\mathrm{AT}_{1} \mathrm{R}$ promotes the activation of NADH/NADPH oxidase and the production of superoxide anion radicals as second messengers $[16,17]$ as well as $B_{1} R$ receptor does when it recognizes the des-Arg-bradykinin $[18,19]$. In this sense, $\mathrm{AT}_{1} \mathrm{R}$ activation induces the expression of $B_{1} R[20,21]$ and both induce a vasoconstriction effect with an increment in blood pressure [19, 22].

Furthermore, during the inflammation process RAAS and KKS are active participants of this process, $\mathrm{AT}_{1} \mathrm{R}$ is upregulated by TNF $\alpha$ [23], IL-6 [24] and IL-1 $\alpha$, but is downregulated by TNF $\alpha$ and INF $\gamma$ combined [25]. Ang-II, through $\mathrm{AT}_{1} \mathrm{R}$, induces IL- 6 release and is inhibited by pyrrolidine dithiocarbamate radical scavenger [26]. On the other hand there is not enough information about cytokines regulating $\mathrm{AT}_{2} \mathrm{R}$ expression. KKS induces allodynia through $B_{1} R$ as part of the role in hyperalgesia [18]; macrophages release TNF $\alpha$ and IL- 1 through the $B_{1} R$ pathway [27]. In lung fibroblasts $B_{2} R$ activation induces the release of IL- 6 and IL-8 [28], and also IL- $1 \beta$ through a NF-кBdependent pathway [28]. In summary, both systems control cardiac muscle contraction, levels of nitric oxide [8, 29], and are involved in the inflammatory response [30,31] and in the blood coagulation state [32, 33].

There is a sustained cross-talk and a counterbalance between RAAS and KKS through the activation and degradation of vasoactive peptides through angiotensinconverting enzyme-I (ACE), which activates angiotensin-I to angiotensin-II and degrades bradykinin to bradykinin (1-5) [34-36]. It is important to note that one of the main metabolic functions of the lungs is the activation and degradation of these peptides [36, 37].

During pathological cardiovascular states, the RAAS is overexpressed, as demonstrated in diseases such as hypertension, atherosclerosis, heart infarction and heart failure. However, recent evidence also indicates its participation in the pulmonary fibrosis induced by bleomycin [38] and bronchial hyperresponsiveness in asthmatic patients [39].

PM exposure has been established as a risk factor for lung and cardiovascular diseases, and RAAS and KKS are involved in the pathophysiology of these afflictions. However, there is not currently enough evidence to confirm whether RAAS and KKS are involved in the response to PM exposure. Ulrich et al. demonstrated that the activity of angiotensin-converting enzyme (ACE) in plasma and its mRNA in the lung decreased after 4 or 7 days of exposure to ECH-93 PM and ozone [40]. Gunisson and Chen reported a 1.5-fold increase in the differential expression of At1r in a lung microarray of double-knockout mice (apoE ${ }^{-/-}$and $\mathrm{LDLr}^{-/-}$) exposed subchronically to ultrafine particulates ( $6 \mathrm{~h} /$ day; 5 days/ week for 4 months) [41]. Li et al. observed ex-vivo vasoconstriction of pulmonary artery rings exposed to PM $(1-100 \mu \mathrm{g} / \mathrm{ml})$, the soluble fraction of the PM, and metals including copper and vanadium. This observation was associated with an activation of MAPK signaling. These effects were completely inhibited by losartan and partially with captopril, a blocker of $\mathrm{AT}_{1} \mathrm{R}$ and an inhibitor of ACE, respectively [42]. Other studies using 
a mouse model of long-term exposure to $\mathrm{PM}_{2.5}$ reported cardiac remodeling observed to be associated with a switch to fetal reprogramming, the induction of fibrosis and hypertrophic markers and the impairment of the myocardial contraction [43, 44]. These processes have been reported to be mediated by RAAS.

There is not currently sufficient evidence to establish whether PM exposure could affect expression of RAAS and KKS elements. We therefore hypothesized that PM regulates expression of RAAS and KKS elements in the lungs, and concurrently in the heart, and these changes are accompanied by antioxidant/inflammation and myocardial gene responses.

The aim of this work was to screen for changes in some RAAS- and KKS-related elements during in vivo acute and subchronic exposures to three main airborne particle fractions (coarse, fine and ultrafine particulates) and to examine: 1) whether the effect of PM on RAAS and KKS elements expression is present in the lungs and concomitantly in the heart, 2) if there is a relationship between the exposures and antioxidant responses (heme oxygenase-1 and gamma-glutamyl-cysteine ligase), and 3) tissue damage by histological evaluation and changes in fetal gene reprogramming.

\section{Results and discussions}

\section{mRNA levels of angiotensin and bradykinin system} related-genes in the lungs

To evaluate whether PM exposure affects the angiotensin and bradykinin systems as an initial response to the toxic effect of the three PM fractions, we evaluated the mRNA levels of three genes of each endocrine system.

We observed an increase in the $K l k-1$ mRNA in the lungs of the groups acutely exposed to FP and UFP, which was the only response of the bradykinin system observed after either exposure. However, the $B 1 r$ and $B 2 r$ mRNA levels showed a tendency to increase after the acute exposure; in the subchronic exposure, we did not observe any response of the bradykinin system genes (Table 1).

Our results demonstrate that, in the lungs, the KKS system responds only after an acute exposure, and the main gene that responded to airborne particulate was $K l k-1$. This is a serine protease enzyme that is necessary to produce kinin peptides. On this basis, particulate less than $2.5 \mu \mathrm{m}$ could interfere with the activation of kinin peptides, which are necessary to activate bradykinin receptors. Bradykinin receptors are involved in the regulation of nitric oxide, the main vasodilator molecule, and are implicated in inflammation and vascular tone regulation. The expression of the bradykinin receptors in the lungs was not significantly altered for any of the exposures (regardless of particle type or duration of exposure). This could have been because both receptors are
Table 1 Particulate matter effects on gene expression of angiotensin and bradykinin systems in the lungs. Semi-quantitative expression results of angiotensin-receptor type-2 (At2r), bradykinin receptor type-1 (B1r) and type-2 (B2r), and kallikrein (KIk-1) enzyme after acute and subchronic exposures

\begin{tabular}{|c|c|c|c|c|}
\hline \multicolumn{5}{|c|}{ Acute exposure } \\
\hline Group & FA & $C P$ & FP & UFP \\
\hline \multicolumn{5}{|l|}{ Gene } \\
\hline \multirow[t]{2}{*}{ At2r } & 1 & 1.3 & 1.85 & 1.32 \\
\hline & $(0.6-1.4)$ & $(0.61-2.17)$ & $(1.1-2.5)$ & $(0.5-1.9)$ \\
\hline \multirow[t]{2}{*}{ B1r } & 1 & 1.05 & 1.3 & 1.08 \\
\hline & $(0.9-1.1)$ & $(0.8-1.2)$ & $(1.01-2)$ & $(0.9-1.1)$ \\
\hline \multirow[t]{2}{*}{$B 2 r$} & 1.1 & 1.1 & 2 & 1.4 \\
\hline & $(0.6-1.2)$ & $(0.9-1.77)$ & $(0.9-3.1)$ & $(1.4-1.7)$ \\
\hline \multirow[t]{2}{*}{$K I k-1$} & 1 & 1.12 & $1.88 *$ & $1.43 *$ \\
\hline & $(0.94-1.1)$ & $(0.76-1.3)$ & $(1.4-2)$ & $(1.1-2.35)$ \\
\hline \multicolumn{5}{|c|}{ Subchronic exposure } \\
\hline Group & FA & $C P$ & FP & UFP \\
\hline \multicolumn{5}{|l|}{ Gene } \\
\hline \multirow[t]{2}{*}{ At2r } & 1 & 0.73 & 0.85 & 0.82 \\
\hline & $(0.8-1.15)$ & $(0.7-1.1)$ & $(0.5-1.1)$ & $(0.6-1.1)$ \\
\hline \multirow[t]{2}{*}{ B1r } & 1 & 0.95 & 1. & 1 \\
\hline & $(0.9-1.2)$ & $(0.9-1.03)$ & $(0.94-1.5)$ & $(0.93-1.1)$ \\
\hline \multirow[t]{2}{*}{$B 2 r$} & 1 & 1.03 & 1.6 & 1 \\
\hline & $(0.9-1.2)$ & $(1-1.2)$ & $(1.15-4.2)$ & $(0.93-1.1)$ \\
\hline \multirow[t]{2}{*}{$K I k-1$} & 1 & 0.84 & 1.78 & 0.92 \\
\hline & $(0.8-1.2)$ & $(0.8-1.1)$ & $(0.7-2.7)$ & $(0.9-1.4)$ \\
\hline
\end{tabular}

Acute exposure was defined as $5 \mathrm{~h}$ per day for 3 days

Subchronic exposure was defined as $5 \mathrm{~h}$ per day, 4 days per week, for 8 weeks All results were corrected using glyceraldehyde 3-phosphate dehydrogenase as a housekeeping gene

AF: Air filtered

CP: Coarse particulate

FP: Fine particulate

UFP: Ultrafine particulate

Data are showed as median and range

* Indicates significantly different from FA

constitutively expressed in the lung tissue, although they can be induced by some cytokines including IL-1 and TNFa. PM exposure is characterized by the induction of cytokine release [8], but we did not observe changes in the expression of these receptors.

On the other hand, major and significant mRNA changes were observed for the At1r and Ace angiotensin system genes in the lungs. These are two of the most important genes in this system and are therapeutic targets in conditions such as hypertension (Fig. 1). For both periods of exposure, we found an increase in the levels of At1r mRNA in the groups exposed to FP and UFP compared with those exposed to FA (Fig. 1a and b). In contrast to the effects observed with FP and UFP fractions, we observed a decrease in At1r mRNA levels in the group 

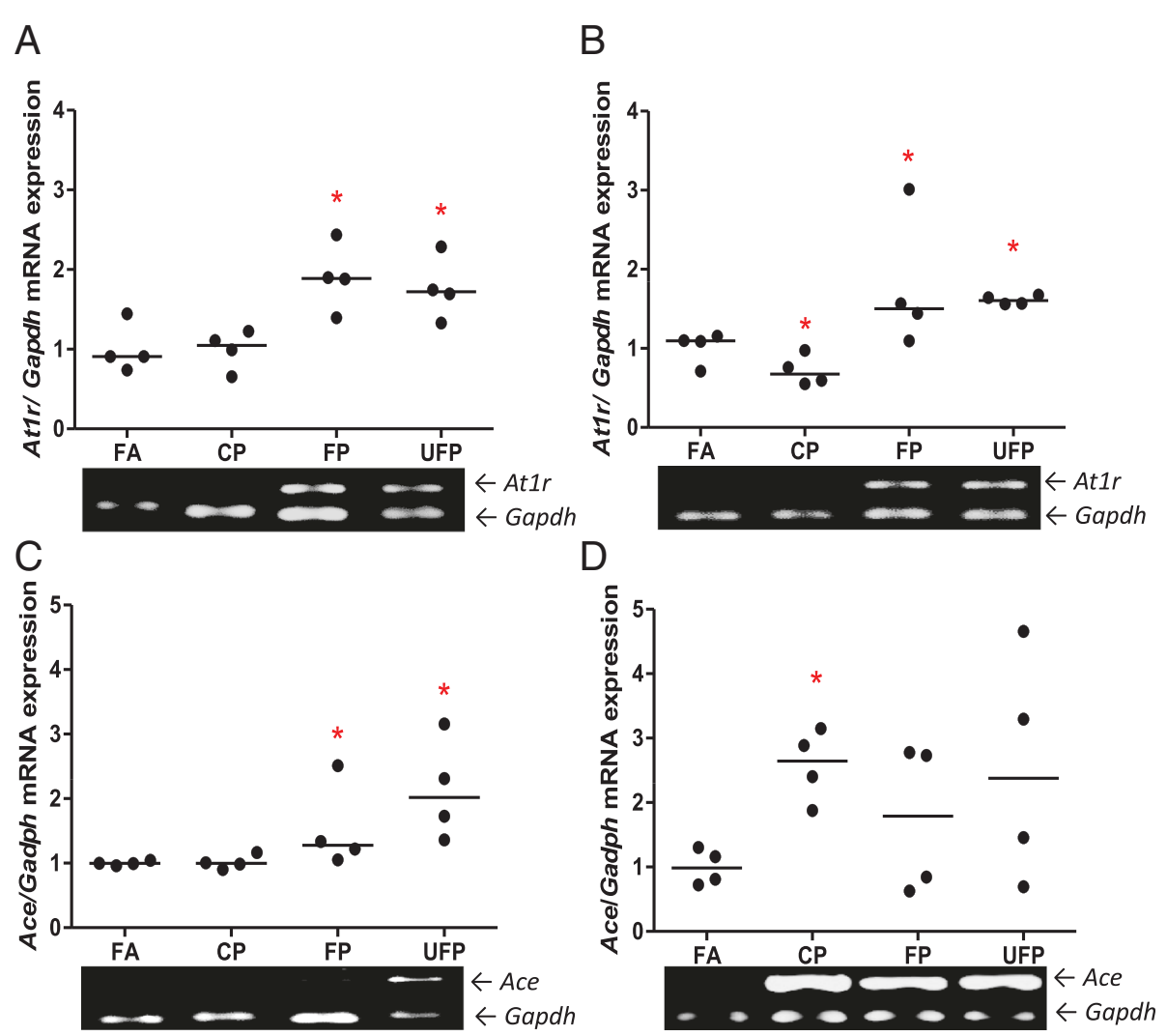

Fig. 1 Particulate matter induces lung $A T_{1} R$ and ACE mRNA in a size- and time-dependent manner. The animals were exposed to coarse (CP), fine (CP) and ultrafine particulate (UFP). A control group was exposed to filtered air (FA). The semi-quantitative levels of Angiotensin Receptor Type-1 (At1r) and Angiotensin-I Converting Enzyme (Ace) mRNA after acute (3 days, $5 \mathrm{~h} / \mathrm{d}$ ) and subchronic ( 8 weeks, $5 \mathrm{~h} / \mathrm{d}, 4 \mathrm{~d} /$ week) exposure are shown. Scatter dot plot shows the value of the median. Below each graph representatives gels illustrating the expression levels of mRNA are shown. ${ }^{*}$ indicates significant differences among groups $(n=4$ per group, $p<0.05)$

subchronically exposed to CP (Fig. 1b). The At2r mRNA levels were not significantly different among any of the types of particle and exposure time conditions as shown in Table 1. Our results for the Ace mRNA levels showed a significant increment following the acute exposures to FP and UFP, but not for the subchronic exposures (Fig. 1c and d). On the other hand, the group exposed subchronically to $\mathrm{CP}$ responded with a large increase in the Ace mRNA relative to all other groups (Fig. 1d). It has been reported that RAAS elements can be expressed constitutively within the cells of various tissues and can have intracrine, paracrine and endocrine effects in the organism [10]. Angiotensin-II is the product of the enzymatic activity of $\mathrm{ACE}$ and is the ligand for $A T_{1} R$ and $A T_{2} R$. Lung tissue expresses these three genes, which are important in the regulation of the pulmonary circulation. As a result of the exposures, At1r and Ace responded to PM, but At2r did not. This suggests that PM exposure modulates the activation of angiotensin-I and the deactivation of bradykinin by up-regulating Ace and promoting At1r up-regulation However, the regulation of At2r, which has been considered to have an antagonistic effect on the At1r signaling pathway, was not affected.
All of these results indicate that PM can regulate two of the principal endocrine systems involved in the regulation of the cardiovascular system at mRNA level. Our data also showed that KKS responds acutely, and not subchronically. On the other hand, the expression of the RAAS genes increased at the end of both exposures, but the responses differed according to the type of particle and the specific genes affected. The mRNA levels of both endocrine systems suggest that KKS and RAAS genes are implicated in the physiological response induced by PM, and these gene expression changes may result in changes in the protein levels.

\section{Protein levels of $A T_{1} R$ and $A C E$ in the lungs}

Following the screening of the expression of RAAS- and KKS-associated genes, we investigated whether the protein levels of $\mathrm{AT}_{1} \mathrm{R}$ and $\mathrm{ACE}$, which demonstrated the most significant changes in the mRNA, were also altered.

In the lung total protein extracts, we observed a statistically significant reduction in the levels of the $\mathrm{AT}_{1} \mathrm{R}$ protein after acute exposures to FP or UFP (Fig. 2a). However, after the subchronic exposure, our results showed an increase in the $\mathrm{AT}_{1} \mathrm{R}$ protein levels for all three particle fractions 

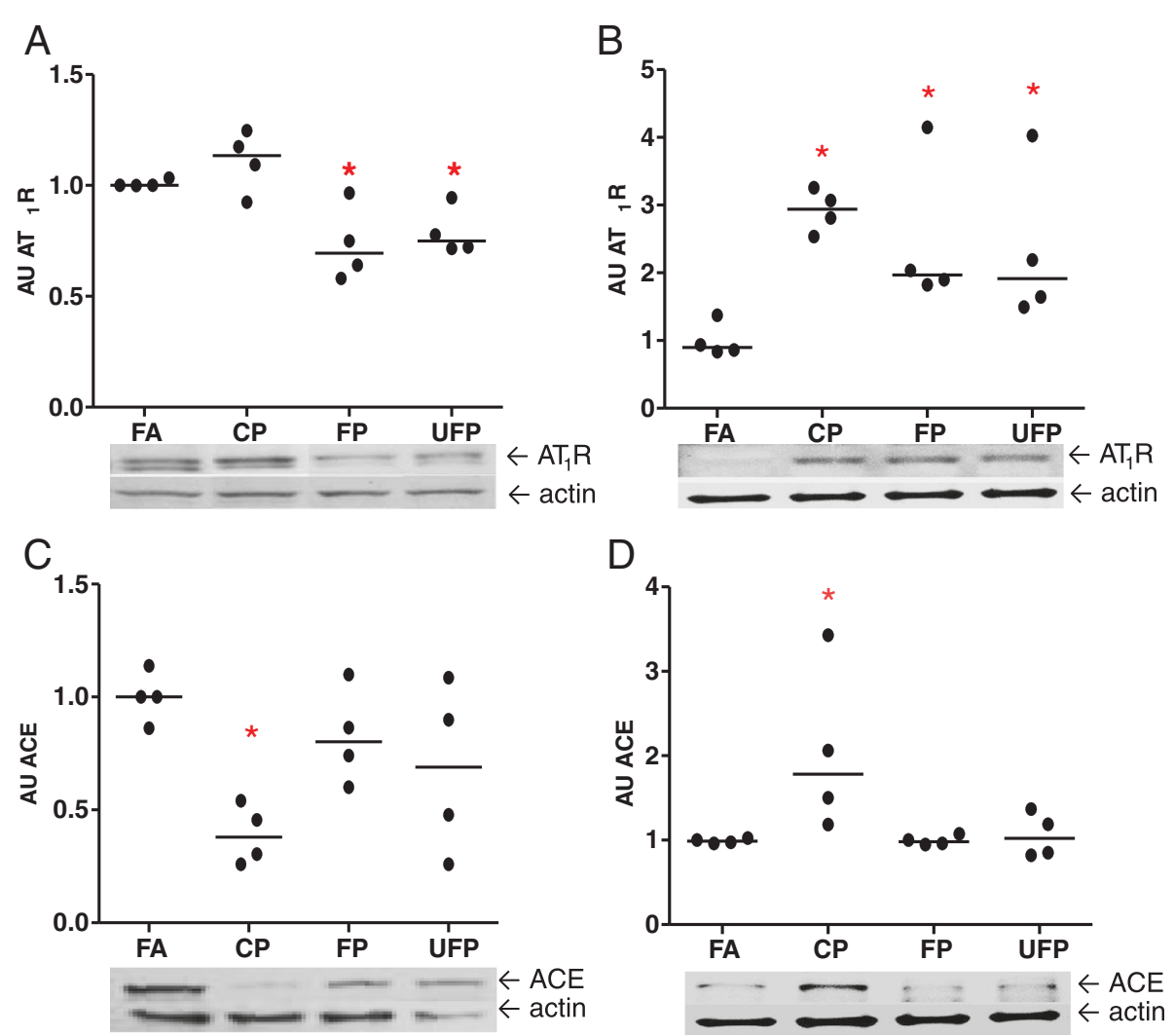

Fig. 2 Particle matter exposure regulates $A T_{1} R$ and ACE protein in a particle size-dependent manner. Animals were exposed to coarse (CP), fine (FP) and ultrafine particulate (UFP), or filtered air (FA). a) and b) The protein levels of Angiotensin Receptor Type-1 (AT, R) and c) and d) Angiotensin-I Converting Enzyme (ACE), after acute (3 days, $5 \mathrm{~h} /$ day) and subchronic (8 weeks, $5 \mathrm{~h} /$ day, 4 days/week) exposure, respectively, are shown as arbitrary units (AU). Scatter dot plot shows the value of the median. ${ }^{*}$ indicates significant differences among groups $(n=4$ per group, $p<0.05)$

(Fig. 2b). Moreover, we observed a decrease in the ACE protein levels after acute exposure to $\mathrm{CP}$, while in the subchronic exposures, an increase in ACE levels was observed. However, for both acute and subchronic exposures to FP and UFP the ACE protein levels were variable. Therefore, although we observed a decrease in the protein levels, the differences were not statistically significant (Fig. 2c and d).

Our results show that exposure to PM was able to induce the $A C E$ and $\mathrm{AT}_{1} \mathrm{R}$ proteins as well as mRNA. Differences were observed with respect to the particle fractions and the target proteins. Acute exposure to $\mathrm{CP}$ caused a downregulation of the ACE protein, without a change of the $\mathrm{AT}_{1} \mathrm{R}$ protein levels. In contrast, the subchronic exposure to $\mathrm{CP}$ induced an increase in ACE protein, which was accompanied by the up-regulation of $\mathrm{AT}_{1} \mathrm{R}$. However, FP and UFP did not affect the ACE protein levels. Instead, $\mathrm{AT}_{1} \mathrm{R}$ was the main molecular target of the FP and UFP fractions. No differences between the FP- and UFP-induced effects on the $\mathrm{AT}_{1} \mathrm{R}$ protein levels were observed. This could be explained either by the fact that UFP are contained within the FP fraction, which precludes separation of their effects, or because they can reach the same region in the lungs, they induce similar responses.
Our data suggest that $\mathrm{PM}$ can regulate $\mathrm{AT}_{1} \mathrm{R}$ and $\mathrm{ACE}$ protein levels in the lungs in a time- and possibly a PM size-dependent manner. It is important to highlight that the $\mathrm{CP}$, for which we did not expect a response, was able to modulate both genes, while the FP and UFP fractions only modulated $\mathrm{AT}_{1} \mathrm{R}$. This evidence confirms that $\mathrm{CP}$ can promote pulmonary events as well as the PM smaller than $2.5 \mu \mathrm{m}$, and suggests a possible contribution to cardiovascular impairment as a consequence of exposure to PM.

\section{$\left[{ }^{3} \mathrm{H}\right]$-Angiotensin-II binding to lung membranes}

Similar to other G protein-coupled receptors, upon activation $\mathrm{AT}_{1} \mathrm{Rs}$ can be internalized from the cell membrane to the cytoplasm and then can be either recycled or degraded. Because the reduction in $\mathrm{AT}_{1} \mathrm{R}$ protein after the acute exposure to FP and UFP did not match the mRNA levels, we performed a binding assay with labeled Ang-II as an alternative method to confirm the protein levels. First, we obtained a saturation curve to determine the receptor density and the affinity for $\left[{ }^{3} \mathrm{H}\right]$-Angiotensin-II in lung membranes obtained from rats that were not used in the PM experiments. These determinations (Fig. 3a) yielded a maximum 

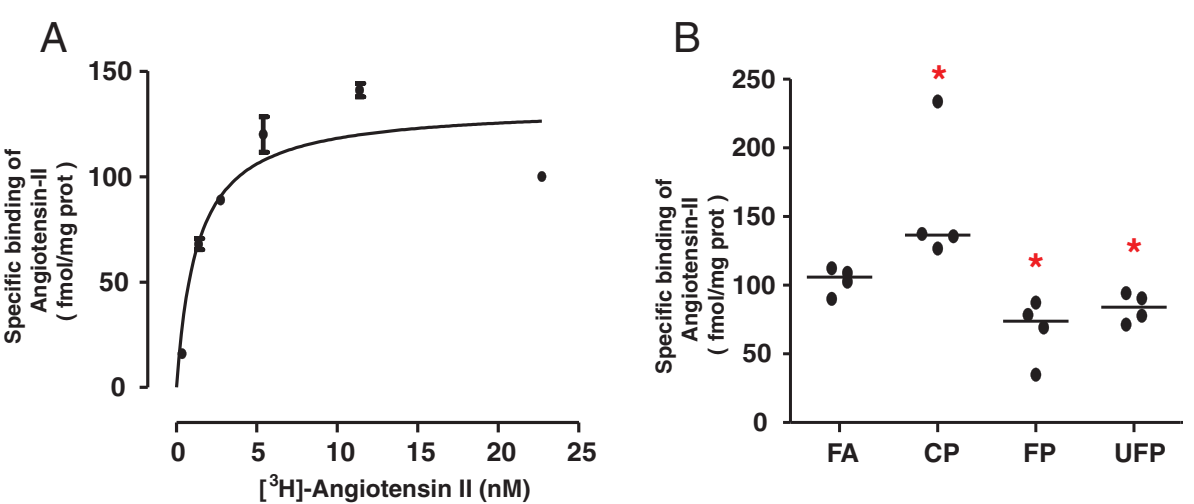

Fig. 3 Acute exposure to PM modifies [ $\left.{ }^{3} \mathrm{H}\right]$-Angiotensin-ll binding to the lung tissue membranes. a) Saturation binding. Membranes, obtained from naive animals as described in Methods, were incubated with the indicated concentrations of $\left.{ }^{3} \mathrm{H}\right]$-Angiotensin-ll. Specific receptor binding was determined by subtracting the binding in the presence of $100 \mu \mathrm{M}$ telmisartan from the total binding. The points show the means from quadruplicate determinations from a single experiment, which was repeated twice more with membranes obtained from different naive animals. The line drawn is the best fit to a hyperbola. Best-fit values for the equilibrium dissociation constant $\left(K_{d}\right)$ and maximum binding $\left(B_{\max }\right)$ are given in the text. b) Single-point determinations. Membranes were obtained from animals exposed to coarse (CP), fine (FP) and ultrafine particulate (UFP) or from the filtered air control group (FA), and then incubated with $10 \mathrm{nM}\left[{ }^{3} \mathrm{H}\right]$-Angiotensin-ll. Specific receptor binding was determined by subtracting the binding in the presence of $10 \mu \mathrm{M}$ telmisartan. Scatter dot plot shows the value of the median. * Indicates significant differences among groups $(n=4$ per group, $p<0.05)$

specific binding $\left(\mathrm{B}_{\max }\right)$ of $90 \pm 10 \mathrm{fmol} / \mathrm{mg}$ protein (3 experiments) and an equilibrium dissociation constant $\left(K_{\mathrm{d}}\right)$ of $2.8 \mathrm{nM}\left(\mathrm{p} K_{\mathrm{d}} 17.2 \pm 7.7\right)$.

In single-point determinations with a near saturating concentration $(10 \mathrm{nM})$ of $\left[{ }^{3} \mathrm{H}\right]$-Angiotensin-II, a reduction in the specific binding was observed in lung membranes from the animals exposed to FP and UFP. In contrast, exposure to $\mathrm{CP}$ increased the specific $\left[{ }^{3} \mathrm{H}\right]$ Angiotensin-II binding (Fig. 3b).

The binding data thus showed the same pattern as the total protein detected immunologically. On this basis, we infer that the internalization and degradation of $\mathrm{AT}_{1} \mathrm{R}$ in the acute exposure could be induced by different mechanisms such as an over-activation, a target of oxidative stress and/or allosteric regulation by divalent cations, similar to observations of other GPCRs $[45,46]$.

\section{$A T_{1} R$ levels in subcellular fractions of lung tissue}

The conventional paradigm for GPCRs indicates that the activated receptors are internalized from the plasma membrane to the cytoplasm where they may be degraded or recycled [47]. However, new evidence indicates that some GPCRs can be localized in the nuclear envelope [48]. In the case of $\mathrm{AT}_{1} \mathrm{R}$, Lu et al. reported that after $15 \mathrm{~min}$ of stimulation of neuronal cell cultures with Ang-II, $\mathrm{AT}_{1} \mathrm{R}$ was sequestered to the nuclear membrane [49]. However, Tadevosyan et al. [50] demonstrated that the presence of angiotensin receptors $\left(\mathrm{AT}_{1} \mathrm{R}\right.$ and $\left.\mathrm{AT}_{2} \mathrm{R}\right)$ in the nuclear membrane is most likely a result of intracellular synthesis and trafficking, and not the result of post-endocytotic trafficking in cardiomyocyte cultures. For these reasons, we evaluated the distribution of $\mathrm{AT}_{1} \mathrm{R}$ protein between the nuclei and the rest of the cell in the lung tissue following exposure to airborne PM in both exposure schemes (Fig. 4). For the acute exposures, we observed an increase in $\mathrm{AT}_{1} \mathrm{R}$ in the non-nuclear fraction in all exposed groups, while in the nuclear fraction we observed a reduction in protein levels (Fig. 4, upper panel). On the other hand, following the subchronic exposures, we observed the opposite response: under these conditions, we observed a decrease in $\mathrm{AT}_{1} \mathrm{R}$ levels in the non-nuclear fraction and an increase in this protein in the nuclear fraction (Fig. 4, lower panel).

On the basis of our findings with respect to the subcellular distribution of $\mathrm{AT}_{1} \mathrm{R}$ in the lung tissue, we suggest that this receptor may mediate processes that include cell proliferation, survival, inflammatory responses, DNA synthesis and transcription as has been demonstrated for other GPCRs found in the nuclear envelope [48]. For example, nuclear $\mathrm{AT}_{1} \mathrm{R}$ activation has been demonstrated using isolated nuclei from fetal rat myocytes. Stimulation of these nuclei with angiotensin-II induced transcription as indicated by $\left[\alpha-{ }^{32} \mathrm{P}\right]$ UTP incorporation, and this effect was inhibited by pertussis toxin [50].

\section{IL-6 cytokine protein levels in lung}

Pleiotropic cytokine IL- 6 is involved in the acute phase of inflammation and accelerates coagulation induced by PM exposure in vivo [5]. In addition, in endothelium cells, IL-6 induced the expression of $\mathrm{AT}_{1} \mathrm{R}$ [24]. We observed a statistically significant increase in lung IL-6 protein from the acute exposure to the three PM fractions (Fig. 5a); on the other hand, in the subchronic exposure a down regulation in the three PM groups below the levels observed in the FA group was observed (Fig. 5b). Our results indicate the induction of lung IL-6 as a marker of the acute phase of the inflammation process. IL- 6 could be involved in the 

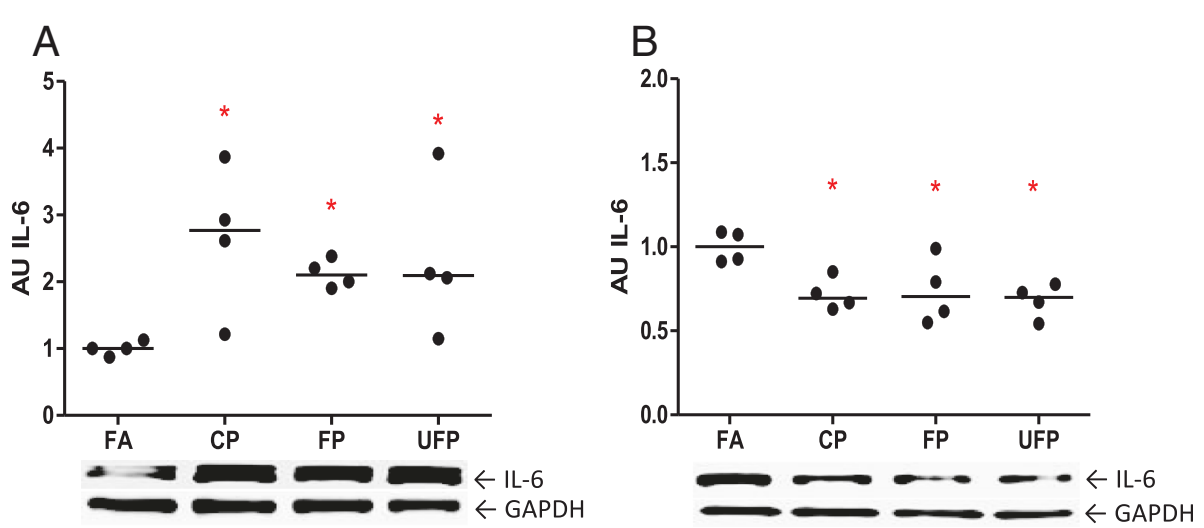

Fig. 4 Particle matter modifies the AT 1 R subcellular distribution in lung tissue in a time-dependent manner. Representative gels of Angiotensin-ll type-l receptor $\left(\mathrm{AT}_{1} \mathrm{R}\right)$ detection in lung nuclear and non-nuclear fractions after acute (upper panel) and subchronic (lower panel) exposure to coarse particulate (CP), fine particulate (FP), ultrafine particulate (UFP) or filtered air (AF). We used GAPDH and acetylated Histone-4 ( $\left.\mathrm{H}_{4} \mathrm{ac}\right)$ as cytosolic and nuclear quality control targets, respectively, and actin was used as a general protein loading control. Representative blot of $n=4$

up-regulation of $\mathrm{AT}_{1} \mathrm{R}$ in lung acute $\mathrm{PM}$ exposure. In contrast, in the subchronic exposure a lack of induction of lung IL-6 protein was observed and $\mathrm{AT}_{1} \mathrm{R}$ expression was increased. If a molecular communication process takes place between IL-6 and $\mathrm{AT}_{1} \mathrm{R}$ it only happens acutely, but not subchronically, yet this hypothesis needs to be confirmed.

\section{Expression of angiotensin and bradykinin system genes} in the heart

The results obtained in the lungs suggest a contribution of the RAAS and to a lower degree, but not less important, of the KKS in the endocrine pulmonary response to PM damage. These heterogeneous responses of gene expression observed in the lungs following the acute and subchronic exposures to airborne particulate fractions could be conveyed from the lungs to the heart.

As expected, we observed a response in the mRNA levels of bradykinin-related genes in the heart following the exposure to PM. Similar to the observations in the lungs, in the heart there was an increase in $K l k-1$ after the acute exposure to FP that was sustained in the subchronic exposure. Additionally, we observed an increase in B1r in all groups

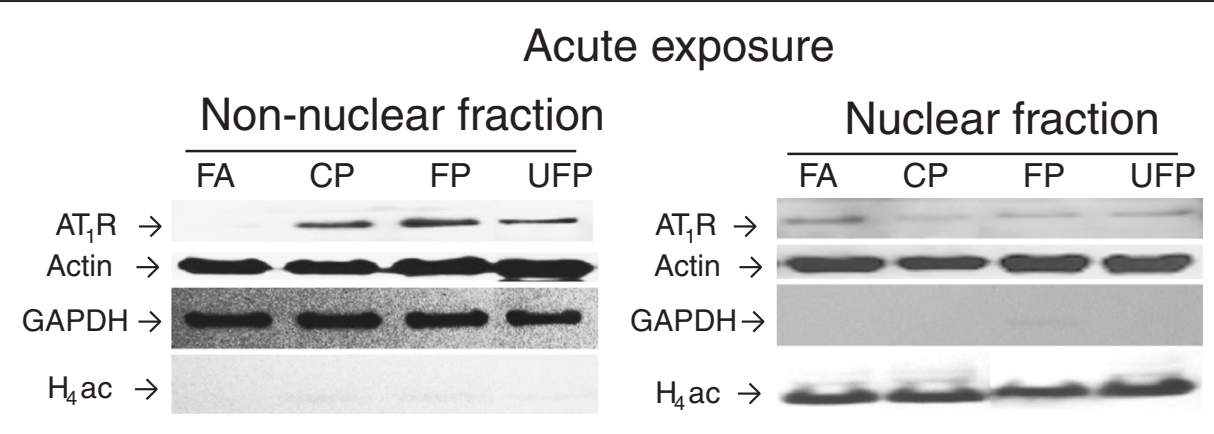

Subchronic exposure

Non-nuclear fraction

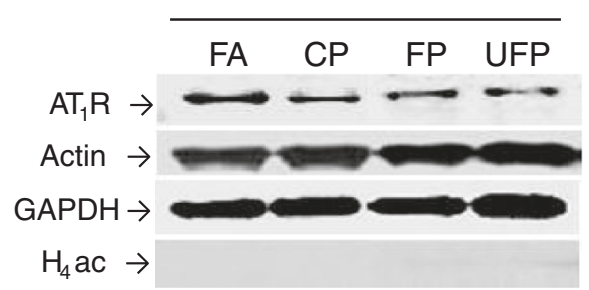

Nuclear fraction

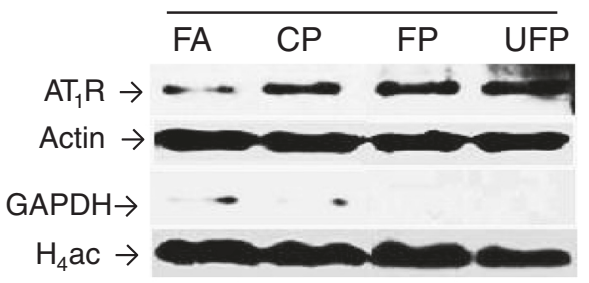

Fig. 5 Acute, but not subchronic, exposure to particle matter increases IL-6 in lungs. Animals were exposed to coarse (CP), fine (FP) and ultrafine particulate (UFP), or filtered air (FA). The protein interleukine-6 (IL-6) levels after a) acute (3 days, $5 \mathrm{~h} /$ day) and b) subchronic exposure ( 8 weeks, 5 h/day, 4 days/week), are shown as arbitrary units (AU). Scatter dot plot shows the value of the median. * indicates significant differences among groups $(n=4$ per group, $p<0.05)$ 
acutely exposed to particulate (Table 2). We were not able to detect $B 2 r$ in the heart samples; no positive amplification was observed in the heart samples from any of the exposure schemes. This observation confirms that, as previously reported, $B 2 r$ is a receptor which has a null or low expression in the heart ventricles of the adult male rat [51-53].

Our results for the expression of KKS genes show that there is a differential response between the lungs and the heart: the heart responded to the exposures to the three particulate with the induction of B1r mRNA. These results suggest that the inflammatory factors or chemical components are released from the lungs and enter in the blood stream of the pulmonary circulation before being translocate to the heart. Although we observed this response to all three particulate, FP, but not UFP, was able to induce $K l k-1$, which indicates that there are differences between

Table 2 Particulate matter effects on gene expression of angiotensin and bradykinin systems in the heart. Semi-quantitative expression results for angiotensin-receptor type-2 (At2r), Bradykinin receptor type-1 (B1r) and kallikrein (Klk-1) enzyme after acute and subchronic exposures

\begin{tabular}{|c|c|c|c|c|}
\hline \multicolumn{5}{|c|}{ Acute exposure } \\
\hline Group & $\mathrm{FA}$ & $\mathrm{CP}$ & FP & UFP \\
\hline \multicolumn{5}{|l|}{ Gene } \\
\hline \multirow[t]{2}{*}{ At2r } & 1 & 1 & 1 & 1 \\
\hline & $(0.8-1.2)$ & $(1-1.1)$ & $(0.9-1.1)$ & $(0.5-1)$ \\
\hline \multirow[t]{2}{*}{ Ace } & 1 & $1.6 *$ & 1.1 & $1.7 *$ \\
\hline & $(0.9-1.1)$ & $(1.4-1.8)$ & $(0.9-1.3)$ & $(1.1-2.1)$ \\
\hline \multirow[t]{2}{*}{$B 1 r$} & 1 & $1.7 *$ & $2.2 *$ & $1.9 *$ \\
\hline & $(0.8-1.3)$ & $(1.4-2.2)$ & $(2.1-2.6)$ & $(1.3-2.4)$ \\
\hline \multirow[t]{2}{*}{$K \mid k-1$} & 1 & 1.2 & $1.6 *$ & $1.4^{*}$ \\
\hline & $(0.8-1.2)$ & $(1-1.5)$ & $(1.4-1.9)$ & $(1.2-1.5)$ \\
\hline \multicolumn{5}{|c|}{ Subchronic exposure } \\
\hline Group & FA & $\mathrm{CP}$ & $\mathrm{FP}$ & UFP \\
\hline \multicolumn{5}{|l|}{ Gene } \\
\hline \multirow[t]{2}{*}{ At2r } & 1 & 0.97 & 0.92 & $0.71 *$ \\
\hline & $(0.96-1.03)$ & $(0.97-1.05)$ & $(0.72-0.9)$ & $(0.7-0.8)$ \\
\hline \multirow[t]{2}{*}{ Ace } & 1 & 1 & 1 & 0.9 \\
\hline & $(0.9-1.1)$ & $(0.9-1.1)$ & $(0.9-1.3)$ & $(0.8-1)$ \\
\hline$B 1 r$ & \multicolumn{4}{|c|}{ Not determined } \\
\hline \multirow[t]{2}{*}{ Klk-1 } & 1 & 1.1 & $1.2 *$ & 1.1 \\
\hline & $(0.9-1.1)$ & $(0.9-1.2)$ & $(1.19-1.22)$ & $(1-1.3)$ \\
\hline
\end{tabular}

Acute exposure was defined as $5 \mathrm{~h}$ per day for 3 days

Subchronic exposure was defined as $5 \mathrm{~h}$ per day, 4 days per week during 8 weeks

All results were corrected with glyceraldehyde 3-phosphate dehydrogenase as a housekeeping gene

AF: Air filtered

CP: Coarse particulate

FP: Fine particulate

UFP: Ultrafine particulate

Data are showed as median and range

* Indicates significantly different from FA these two particle fractions and suggests that FP could affect the metabolism of kinin peptides.

With respect to the angiotensin system, the heart At $2 r$ mRNA levels were not significantly different among the acute exposure groups. In contrast, subchronic exposure to UFP caused a significant decrease in the heart At2r levels (Table 2). The Ace mRNA increased after acute exposure to either CP or UFP, but these changes did not persist in the subchronic exposure (Table 2). We observed an increase in the At1r mRNA levels after acute and subchronic exposure to FP, as well as in the group after the subchronic exposure to UFP (Fig. 6).

The cardiac over-expression of $\mathrm{AT}_{1} \mathrm{R}$ has been demonstrated to be involved with the promotion and exacerbation of myocardial impairment. It is relevant to note that short PM exposure was able to induce At1r, which was maintained in the subchronic exposure. This observation was accompanied with a down-regulation of At2r only after the subchronic exposure, indicating that exposure to $\mathrm{PM}$, an environmental air pollutant, can increment the expression of At1r in the absence of counterbalancing changes in the expression of At2r.

\section{Up-regulation of Col3a1 and Acta1 in presence of $\mathrm{AT}_{1} \mathrm{R}$ and IL-6 in the heart}

Two of the main classes of response genes in the heart during pathological states of cardiac damage are the heart fetal reprogramming genes and the expression of genes involved in the deposition of the extracellular matrix. We chose alpha skeletal actin (Acta1) and collagen-III (Col3a1) as two representative markers of myocardial adaptive response to damage. We analyzed these genes in heart ventricular samples after the acute exposures, and did not observe any response in either gene (data not show). In contrast, the subchronic exposures to FP and UFP induced the up-regulation of Acta1 and Col3a1 (Fig. 7a and b).

Our results indicate that PM is not able to acutely upregulate these genes, but they are increased by subchronic exposure. The presence of these two markers in various rat cardiac disease models has been described, i.e., hypertension or induced cardiac infarction [54]. FP and UFP have been associated predominantly with the enhancement of the development of cardiovascular diseases. Our results confirm that particulate less than $2.5 \mu \mathrm{m}$ are able to up-regulate gene reprogramming in the heart, possibly by through an increase in blood pressure.

There is substantial evidence to support the concept that RAAS induces heart gene reprogramming [54-57]. For this reason, we evaluated $\mathrm{AT}_{1} \mathrm{R}$ total protein levels in samples from the subchronic exposure where we observed heart gene reprogramming. We also observed an increase in the levels of $\mathrm{AT}_{1} \mathrm{R}$ in the total protein that seems PM sizedependent, where the highest increase was observed for UFP followed by FP and to a lower degree for CP (Fig. 7c). 

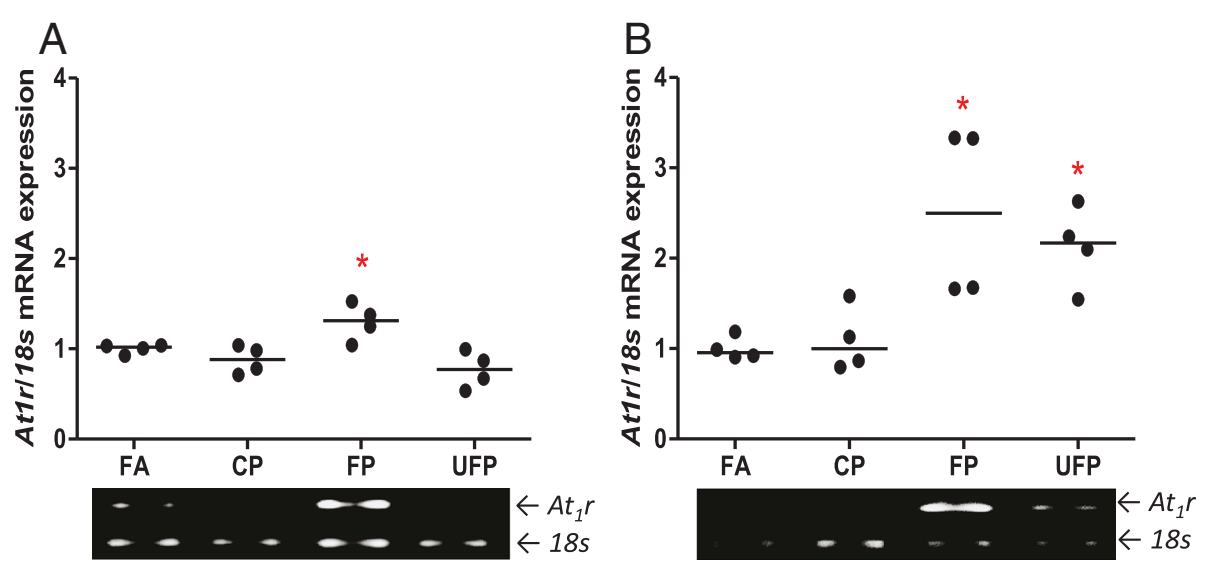

Fig. 6 Acute and subchronic exposures to fine and ultrafine PM up-regulate heart AT $R$ mRNA. The animals were acutely ( 5 h/day, 3 days) or subchronically ( 5 h/day, 4 days/week, 8 weeks) exposed to coarse (CP), fine (FP) and ultrafine particulate (UFP) or to filtered air (FA). Semi-quantitative levels of Angiotensin Receptor type-1 (At 1r) mRNA after a) acute and b) subchronic exposures in the heart. Scatter dot plot shows the value of the median. * indicates significant differences among groups ( $n=4$ per group, $p<0.05$ )

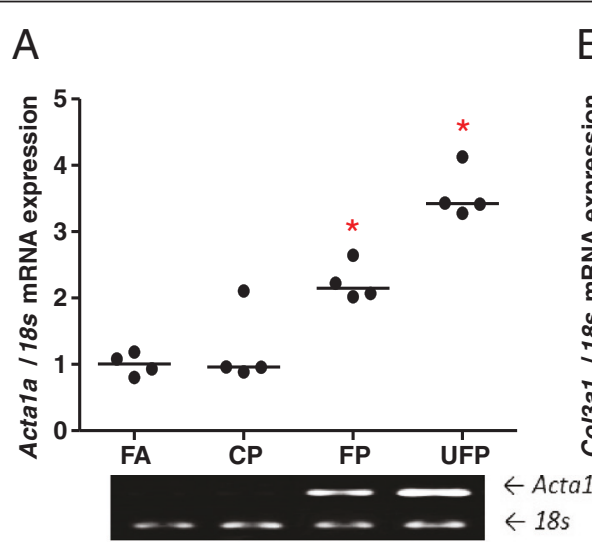

\section{B}

C

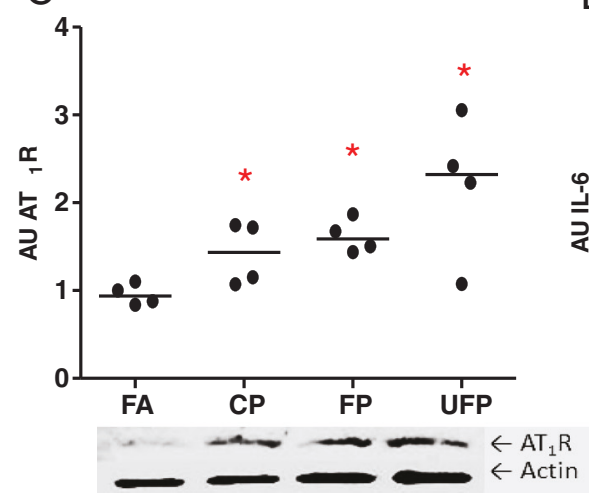

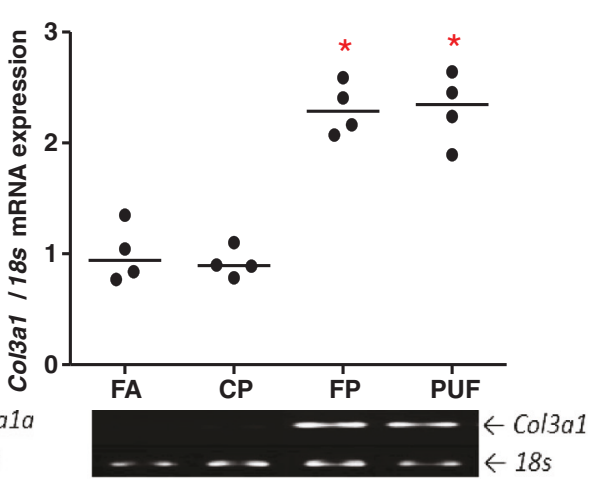

$\mathrm{D}$

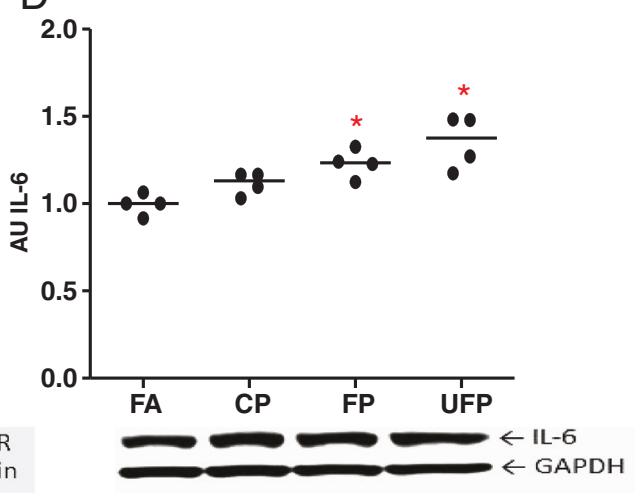

Fig. 7 Subchronic exposure to fine and ultrafine PM induces heart reprogramming and up-regulates AT $R$ and IL-6. The animals were subchronically exposed ( 5 h/day, 4 days/week for 8 weeks) to coarse (CP), fine (FP) and ultrafine particulate (UFP) or to filtered air (FA). a) Semi-quantitative levels of alpha-skeletal actin (Acta 1a) mRNA and b) Semi-quantitative levels of collagen-III (Col3a1) mRNA in the heart. Protein levels of AT R and interleukin-6 $(\mathrm{IL}-6)$ are expressed in arbitrary units $(\mathrm{AU}), \mathbf{c})$ and $\mathbf{d})$, respectively. Scatter dot plot shows the value of the median. ${ }^{*}$ indicates significant differences among groups $(n=4$ per group, $p<0.05)$ 
IL-6 cytokine is involved in the induction of $\mathrm{AT}_{1} \mathrm{R}$ in the endothelium; also Ang-II through $\mathrm{AT}_{1} \mathrm{R}$ induces the expression of cardiotrophin-1, leukemia inhibitory factor and IL-6, all which are members of IL- 6 family. In rodent cardiac fibroblast these cytokines induce cardiomyocyte hypertrophy through the activation of gp130, which is a IL-6 receptor [58]. In this sense, we evaluated IL-6 protein levels, as a marker of inflammation response, in the heart and observed an increment in IL- 6 that could be size-dependent where FP and UFP showed statistical significant differences (Fig. 7d) and they have the same tendency as the $\mathrm{AT}_{1} \mathrm{R}$ in the heart. Our findings suggest that IL- 6 and $A_{1} T_{1}$ are induced in heart by PM exposure and is possibly size particulate-dependent; also, IL-6 and $\mathrm{AT}_{1} \mathrm{R}$ show the same behavior as cardiac reprogramming genes induced by FP and UFP.

\section{Histology of intramyocardial coronary arteries}

One effect of RAAS in the heart tissue is hypertrophy and proliferation of the smooth muscle cells of the blood vessels. We evaluated the thickness of the intramyocardial coronary arteries (we considered only arteries found within the myocardium wall, but not in the epicardium or endocardium) as a morphological effect in myocardial tissue induced from the particle exposure and found that the exposure to the three particle fractions increased the intramyocardial coronary artery wall thickness (Fig. 8a and $\mathrm{c}$ ). This result is consistent with the induction of $\mathrm{AT}_{1} \mathrm{R}$ with the three fractions and suggests the activation of RAAS.

It has been proposed that particulate less than $2.5 \mu \mathrm{m}$ can pass through the lung respiratory and vascular walls and reach the heart through the pulmonary circulation $[48,59]$. A particular observation in this study was the presence of mononuclear cells, which seem to be macrophages as they display fried egg-like morphology, next to the arteries in the heart from the UFP group and to a minor degree from the FP group (Fig. 8c). This observation suggests an immune cellular response at the end of the subchronic exposure to FP and UFP.

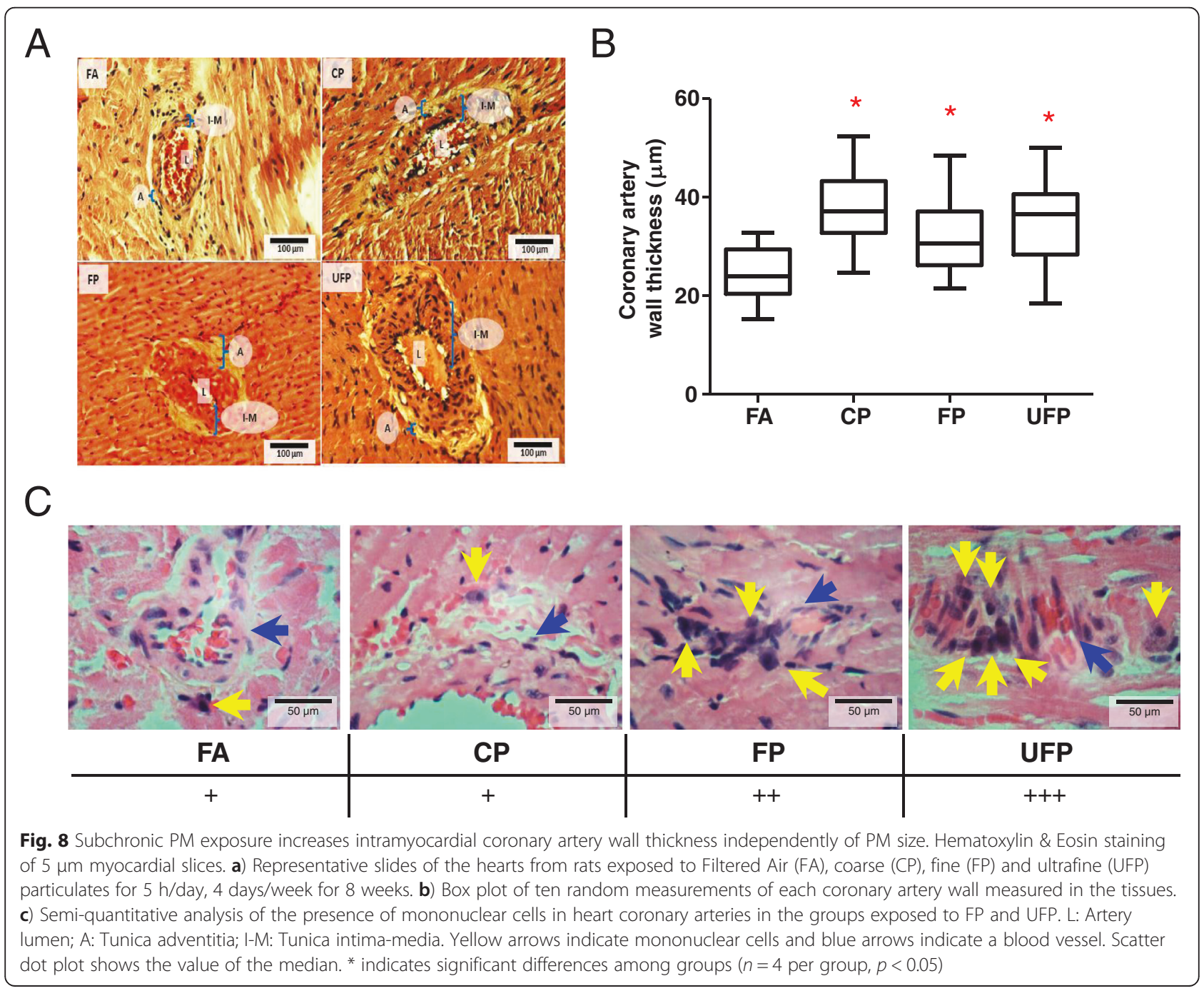




\section{Lungs and heart subchronic antioxidant response}

Finally, one of the most important responses to particulate exposure is the antioxidant defense. We evaluated the protein levels of $\gamma$-glutamyl-cysteine-synthetase catalytic subunit $(\gamma \mathrm{GCSc})$, and heme oxygenase type-1 (HO-1) in the lungs and heart after subchronic exposure to airborne PM. We did not observe significant changes in $\gamma \mathrm{GCSc}$ protein levels in either tissue (data not shown). However, the lung levels of HO-1 seem to decrease in a particulate size-dependent manner, where the greatest down-regulation was observed in the UFP group (Fig. 9a). The same tendency was observed for the heart levels of $\mathrm{HO}-1$, but only the effects of UFP were statistically significant (Fig. 9b).

We did not observe differences in $\gamma$ GCSc protein levels in lungs and heart even though glutathione is one of the first antioxidant defenses against oxidative stress. Also, although $\gamma \mathrm{GCSc}$ is involved in the de novo synthesis of glutathione the toxic effect of PM may be directly modifying the reduced and oxidized glutathione ratio and diminish total glutathione levels, as it has been reported for different progressive lung diseases [60]. Also, other antioxidant response elements such as ascorbic acid, which is abundant in the rat lung, or HO-1 and bilirubin in the cardiovascular system, could be involved in the response against PM-induced oxidative toxicity [61].

$\mathrm{HO}-1$ is an inducible stress protein enzyme that has major role in cytoprotective defense against apoptosis, inflammation and oxidative stress through the catabolism of the heme moiety and the release of $\mathrm{Fe}^{2+}$, biliverdin and $\mathrm{CO}$. The latter two metabolites are implicated in the antioxidant response and vascular tone, respectively [62-64]. Low HO-1 levels have also been shown to be associated with an impairment of the cardiovascular system [65] and the development of lung diseases [66]. In addition, HO-1 levels can be down-regulated at the mRNA and protein levels by angiotensin-II through $\mathrm{AT}_{1} \mathrm{R}$ in rat vascular smooth muscle cells [67]. Evidence from in vitro models (RAW 264.7, THP-1, BEAS-2B and A549 cells) exposed to PM indicated that the induction of $\mathrm{HO}-1$ depended on the PAH content of the PM [68-70]. However, exposure of A549 cells to 9,10-phenanthraquinone down-regulated the expression of HO-1 [71]. Acute in vivo studies demonstrate increases in $\mathrm{HO}-1$ protein and mRNA. Nevertheless, in older current smokers, HO-1 mRNA is downregulated [72]. Furthermore, it has been observed in human populations that a larger size of the dinucleotide repeat polymorphism (GT) $\mathrm{n}$ in the HO-1 gene confers a low induction of mRNA by tobacco smoke and is related to the development of emphysema [73]. The same polymorphism has been associated with a low induction and the development of coronary artery disease [74]. Moreover, oxidative stress during the subchronic exposure to PM is likely to be neutralized by non-enzymatic antioxidants derived from enzymatic antioxidant elements, such as heme-metabolism/HO-1/bilirubin-biliverdin biochemical route, these products, bilirubin and biliverdin, play the main antioxidant role, thus the induction of $\mathrm{HO}-1$ is probably not the primarily antioxidant biomarker in response to the subchronic exposure.

\section{General overview}

PM pollution contributes to the development of cardiovascular diseases. Our results indicate that in addition to inflammation and oxidative stress, exposure to PM induces an endocrine response through the expression of some RAAS and KKS elements. This effect could be dependent on the particle size, the tissue type and the time of exposure, and could participate in cardiovascular events.
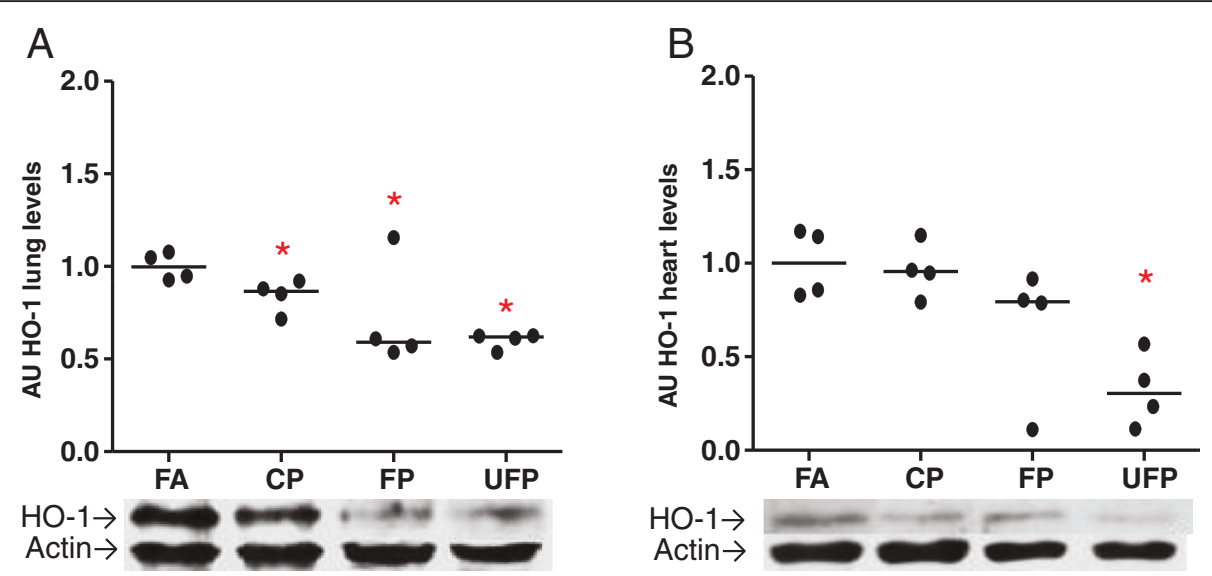

Fig. 9 Particle size-dependent decreases in heme oxygenase-1 after subchronic exposure in the lungs and heart. Animals were exposed subchronic to coarse (CP), fine (FP) and ultrafine particulate (UFP) or to filtered air as a control (FA) for 8 weeks ( $5 \mathrm{~h} /$ day, 4 days/week). Protein levels of heme oxygenase-1 (HO-1) in arbitrary units (AU) in lungs $\mathbf{a}$ ) and heart $\mathbf{b})$. Scatter dot plot shows the value of the median. * indicates significant differences among groups ( $n=4$ per group, $p<0.05)$ 
The KKS acute exposure response was characterized by the induction of the $K l k-1$ in the lungs and heart of the groups exposed to FP and UFP. Expression of $K l k-1$ leads to the generation of kinin peptides through the breakdown of KNG in tissues. However, this enzyme also can have other substrates such as pro-renin, pro-insulin, LDL, the precursor of atrial natriuretic factor, pro-collagenase, vasoactive intestinal peptide and ANG. Despite the many substrates of KLK-1, it has been reported that KLK-1 improves cardiac physiology reducing blood pressure, prevents the increment in heart mass, reduces the septal thickness and cardiomyocyte size in hypertrophic animal models after aortic constriction. Also, in these animals KLK-1 contributes to decrease the NADPH oxidase activity and increases $\mathrm{NO}$ production through $\mathrm{B}_{2} \mathrm{R}$ [75]. Moreover, $k l k-1$ null mice do not show alteration in blood pressure but exhibited abnormal structures (thin wall and diminished mass of the left ventricle) and functions (reduced cardiac output, stroke volume and left ventricular fractional shortening) of the heart [76].

The above evidence indicates the importance of KLK-1 in the physiology of the cardiovascular system, in addition, kallikrein family genes have been proposed as emerging new markers for the development of cancer [77], and have been weakly associated with the development of lung diseases. It has been demonstrated that KLK-1 is abundant in the lung lavage from asthmatic patients challenged with allergen [78], as well as in an allergic sheep model. Furthermore, a monoclonal antibody to KLK1 inhibited allergen-induced late-phase bronchoconstriction and airway hyper-responsiveness to carbachol. Additionally, in human tracheobronchial epithelial cells, this antibody blocked oxidative stress-induced epidermal growth factor receptor activation and mucus hypersecretion [79].

This evidence suggests that in the lung KLK-1 seems to be involved in the triggering of local inflammatory response, through breakage of KNG zymogen to bradykinin and kallidin by KLK-1. Bradykinin and kallidin are further broken by the membrane-bound carboxypeptidase- $\mathrm{M}$ into des-Argbradykinin and des-Arg-kallidin peptides, which activates $\mathrm{B} 1 \mathrm{R}$ that is an important inflammatory mediator [8].

For these reasons, the induction of $K l k 1$ by FP and UFP suggests that the generation of kinin peptides or other substrates of KLK1 could be modified by the PM-induced activation.

The bradykinin receptors did not show a response in the lungs at any time of exposure. However, in the heart, the expression of $B 1 r$ increased after the acute exposure in the three PM-exposed groups. B1r can be induced by inflammatory cytokines, and it can regulate the induction of iNOS enzyme. Thus, our results indicate that the three fractions of particulate could induce the release of secondary mediators from the lungs to the heart, where they were able to induce $B 1 r$.
With respect to RAAS, we observed that At2r did not change significantly at any exposure times in the lungs. In the heart, we only observed a decrease in the mRNA for this receptor after the subchronic exposure to UFP. The lack of response of $A t 2 r$ indicates that PM mainly promotes At1r expression more than the other mRNAs.

Ace is of particular interest because it can be a target of PM toxicity due to having a zinc prosthetic group that could be replaced by other divalent cations. Furthermore, this enzyme can activate angiotensin and degrade bradykinin. We observed that the ACE mRNA and protein in the lungs were regulated mainly by $\mathrm{CP}$, and not by FP and UFP, most likely because CP can only reach the bronchial branches and does not penetrate the lungs as deeply as FP and UFP. Future studies should be conducted to determine whether ACE protein is degraded or is released from the lungs to the blood stream after acute exposure to PM. This is important given that new evidence indicates a novel pathway in which activated ACE can be released from the cell membrane [80-83].

The principal finding of our work was that PM regulates $\mathrm{AT}_{1} \mathrm{R}$ after acute and subchronic exposure. Although $\mathrm{CP}$ did not induce the mRNA for $\mathrm{AT}_{1} \mathrm{R}$, it was able to increase the protein levels of this receptor as observed using the binding assay and Western blotting. The potential mechanism for the increase in $A_{1} R$ protein without the mRNA up-regulation in the CP group, it could be explained as reported by Mori et al. [84], cis-acting sequences in the $\mathrm{AT}_{1} \mathrm{R}$ gene and the glucocorticoid-responsiveness elements control the transduction process, however, AUG codon in the 5'-leader of $\mathrm{AT}_{1} \mathrm{R}$ transcripts play a role in the translation regulation of $\mathrm{AT}_{1} \mathrm{R}$ protein, future research is necessary to confirm this hypothesis. These results confirmed that CP may contribute in the development or promotion of lung and heart diseases, through the increase of Ang-II binding and the regulation of ACE.

With respect to FP and UFP, we know that the UFP fraction is included within the FP fraction. For some parameters that we evaluated, such as mRNA and protein levels, both fractions induced the same degree of response in the lungs. However, we were able to distinguish different responses between the fractions in the heart expression of Acta1, HO-1 and $\mathrm{AT}_{1} \mathrm{R}$ proteins. Thus, differences between FP and UFP can be attributed to the different composition and the deposition sites in the respiratory tract reached by these two different particulate types.

Particle chemical composition has an important role in particle-induced toxicity because it can promote oxidative stress through chemical catalysis or metabolism and can enhance inflammatory responses. Previously, the chemical composition of $\mathrm{PM}_{10}$ and $\mathrm{PM}_{2.5}$, including the metal and organic partial composition was reported by Guerra et al. [85]. The total metal mass concentrations of the CP and FP were 5488.89 and $2992.11 \mathrm{ng} / \mathrm{m}^{3}$, respectively. We 
estimated the percent of each metal mass contribution from the total metal mass of CP and FP based on the results from Guerra et al. [85] (Table 3). For ten metals (Fe, $\mathrm{Zn}, \mathrm{Pb}, \mathrm{Mn}, \mathrm{Cr}, \mathrm{Cu}, \mathrm{Ni}, \mathrm{V}, \mathrm{Co}$ and $\mathrm{Cd}$ ), we found that the element with greatest mass contribution to $\mathrm{CP}$ and FP was $\mathrm{Fe}$, at 38.5 and $48.4 \%$, respectively. The second most abundant element contributing to the $\mathrm{CP}$ and FP masses was $\mathrm{Zn}$, at 37.9 and $12.1 \%$, respectively. The rest of the metals had a minor contributions to particle mass (less than $12 \%$ ), but some elements are more abundant in FP than $\mathrm{CP}$. For example we found more $\mathrm{Cd}$ in $\mathrm{FP}$ than $\mathrm{CP}$ (44.6 times), followed by Co (6.7 times); V (5.1 times); $\mathrm{Cu}$ (2.6 times); $\mathrm{Mn}$ (2.2 times) and $\mathrm{Pb}$ (1.2 times). Biologically relevant effects of the particle composition on RAAS were reported by Li et al. [42], who demonstrated that particle constituents such as $\mathrm{V}$ and $\mathrm{Cu}$ induce pulmonary artery vasoconstriction through $\mathrm{AT}_{1} \mathrm{R}$ and $\mathrm{ACE}$. According to the authors, other metals including $\mathrm{Ni}, \mathrm{Fe}, \mathrm{Mn}, \mathrm{Zn}$ and $\mathrm{Al}$ produced a weak or no effect on vasoconstriction. Based on the percent contribution to the mass, $\mathrm{Zn}$ was one of the most abundant. It was shown that $\mathrm{Zn}$ contained in PM inhibits total cardiac aconitase activity, induces mitochondrial DNA damage, and causes modest changes in the cardiac expression of mRNAs involved in signaling, ion channel function, oxidative stress, mitochondrial fatty acid metabolism and cell cycle regulation [86].

On the basis of the information presented above and considering the metal composition of the PM in our study, we suggest that the biological effects observed could be related to the presence of divalent metals that are able to mimic prosthetic groups, such as $\mathrm{Zn}$ in the ACE enzyme, or mediate oxidative stress and promote inflammation and thus up-regulate $\mathrm{AT}_{1} \mathrm{R}$. Although $\mathrm{CP}$ and FP share some components, we suggest that the biological effect attributed to PM-associated metal content is related to the sites in the lungs reached by the particulate and their potential to translocate beyond the lungs.

Table 3 Metal mass contribution in coarse (CP) and fine PM (FP) from subchronic exposure

\begin{tabular}{lcc}
\hline Metal & CP \% & FP \% \\
\hline $\mathrm{Fe}$ & 38.5 & 48.4 \\
$\mathrm{Zn}$ & 37.9 & 12.1 \\
$\mathrm{Mn}$ & 5.0 & 11.1 \\
$\mathrm{~Pb}$ & 6.9 & 8.3 \\
$\mathrm{Cu}$ & 4.0 & 10.3 \\
$\mathrm{Cr}$ & 4.8 & 1.7 \\
$\mathrm{~V}$ & 1.0 & 5.0 \\
$\mathrm{Co}$ & 0.2 & 1.2 \\
$\mathrm{Cd}$ & 0.03 & 1.2 \\
$\mathrm{Ni}$ & 1.7 & 0.7 \\
\hline
\end{tabular}

In this study it was not possible to assess UFP mass and collect it for chemical determination. However, evidence in the literature [87-89] allows to propose the participation of divalent metals (i.e., $\mathrm{Zn}, \mathrm{Cu}, \mathrm{Cd}$, etc.) as the UFP-chemical components mostly involved in the induction of the effect on RAAS and KKS. Moreover, we do not discard that some other components (i.e., endotoxin and possibly other metals) may also contribute to induce this effect as a secondary response of the release of inflammatory mediators.

While particle composition and possibly oxidative stress could explain the expression of $\mathrm{AT}_{1} \mathrm{R}$, the second most important mechanism of toxicity from the exposure to $\mathrm{PM}$ is the inflammatory process. Two cytokines associated with $\mathrm{AT}_{1} \mathrm{R}$ expression are the pleiotropic cytokine IL-6 $[24,90]$ and growth factor TGF- $\beta$ [91, 92], both of which are also involved in the pathological states of lung and heart disease. We evaluated IL-6 levels as an inflammation marker as well as an $\mathrm{AT}_{1} \mathrm{R}$ inductor. We observed that an inflammation response was present in our experimental model in the lungs and heart. These data suggest that IL-6 may participate in the regulation of $\mathrm{AT}_{1} \mathrm{R}$ in the acute phase of the PM exposure but not in the subchronic exposure in the lung. We suggest that in the subchronic exposure the RAAS by itself maintains the induction of $A T_{1} R$, or inflammatory and/or oxidative stress responses in the lungs may also be involved. On the other hand, heart IL-6 levels in the subchronic exposure seem to increment in a size-dependent manner as well as we observed in the heart $\mathrm{AT}_{1} \mathrm{R}$ protein. However, future studies should focus to establish whether IL-6 is determinant in the induction of $\mathrm{AT}_{1} \mathrm{R}$ in the heart since it has been reported that cytokines such as TNF $\alpha$ [23] and IL-1 $\alpha$ [25] are involved in the induction of $\mathrm{AT}_{1} \mathrm{R}$ in rat cardiac fibroblast and smooth muscle cells, respectively.

It is important to highlight that the differences in the PM concentration achieved in the chambers could directly influence the biological responses observed in the present study. The chamber PM concentrations were $\sim 32 \mu \mathrm{g} / \mathrm{m}^{3}$ for CP, $\sim 178 \mu \mathrm{g} / \mathrm{m}^{3}$ for FP, and $\sim 107 \mu \mathrm{g} / \mathrm{m}^{3}$ for UFP. These concentrations suggest the possibility that the highest biological responses should be observed in PM concentrationresponse relationship, nevertheless, our data seems to indicate that the molecular targets (e.g., $\mathrm{AT}_{1} \mathrm{R}, \mathrm{HO}-1$ etc.) respond in a particulate size-dependent manner. However, some biological responses were independent of the concentration or the particle size such as the B1r expression in heart in the acute exposure, lung IL-6 levels or the intramyocardial thickness, and could be influenced by PM composition, yet this hypothesis needs to be confirmed. Moreover, we have to consider that our results, based in our experimental design, have uncertainty from other factors that include the detailed PM chemical content, the retained dose and the intrinsic biological background. 
Future directions of our study should focus in $\mathrm{AT}_{1} \mathrm{R}$ independent ligand-activation since it has been reported that $\mathrm{AT}_{1} \mathrm{R}$ can function as a mechanoreceptor that under mechanical stretch in vitro may induce RAAS elements [93, 94], and probably the physical interaction of $\mathrm{PM}$ with $\mathrm{AT}_{1} \mathrm{R}$ in the cellular membrane may influence the activation of $\mathrm{AT}_{1} \mathrm{R}$ pathway.

Finally, our results demonstrate that the three fractions of PM were able to modulate their effects through the deregulation of two endocrine systems involved in pulmonary and cardiovascular pathology. These effects could result from the development of the inflammation and oxidative stress processes feeding back on the response of the RAAS.

In this sense our results suggest that the cardiac effect of PM is consequent to a neuro-endocrine stimulation, which includes RAAS and KKS response, probably by mediating vascular tone dysfunction (i.e., hypertension) in the lung as well as in the heart. The augmented $A_{1} R$ expression observed in this study in the lungs and heart may be related with both processes.

\section{Conclusion}

Exposure to PM is detrimental to human health. Oxidative stress and inflammation are the major mechanisms that contribute to the impairment of the lung and cardiovascular systems. Furthermore, in the present study we observed that PM induces the expression of the endocrine system RAAS and KKS elements in a timeand probably in a particulate size-dependent manner. PM primarily promotes the expression of $A_{1} R$ in the lungs and heart, which appears to be involved in the depletion of the antioxidant HO-1, as well as the tissue remodeling and heart gene reprogramming resulting from a subchronic exposure to FP and UFP, concomitantly, PM induces acute IL-6 response in the lung and subchronic response in the heart. Thus, these findings contribute to the understanding of the underlying mechanisms involved in the development of cardiac disease associated with PM exposure.

\section{Methods}

\section{Inhalation exposure}

The present study was carried out in the north of Mexico City, an area with high traffic affluence and industrial activity [95], during the months of May to July, 2009. The particulate concentrator was localized within the Animal Care Unit at CINVESTAV-IPN.

Male Sprague Dawley rats (purchased from Harlan, Mexico; 4 rats/group) were exposed acutely (3 days, $5 \mathrm{~h}$ per day) and subchronically (8 weeks, 4 days/week, $5 \mathrm{~h}$ per day) to coarse (CP), fine (FP), or ultrafine (UFP) particulate using an aerosol enrichment concentrator system. A control group was exposed to filtered air (FA). The FP fraction was defined as particulate less than or equal to $2.5 \mu \mathrm{m}$, which includes the UFP fraction. The particulate concentration in the exposure chambers was 32, 178 and $107 \mu \mathrm{g} / \mathrm{m}^{3}$ for CP, FP, and UFP, respectively. Simultaneous air ambient concentration of $\mathrm{PM}_{10}$ and $\mathrm{PM}_{2.5}$ were monitored and those results were accompanied with the partial chemical composition of $\mathrm{PM}_{10}$ and $\mathrm{PM}_{2.5}$ in the study developed and reported by Guerra-García et al. [85].

At the end of the each exposure ( $24 \mathrm{~h}$ after the last exposure), the animals were anesthetized (i.p. $10-20 \mathrm{mg} / \mathrm{kg}$ of sodium pentobarbital) and euthanized by exsanguination. The lung and heart tissues were dissected and frozen in liquid nitrogen and stored at $-70{ }^{\circ} \mathrm{C}$ until analysis. A ventricular slice of the heart was fixed in $10 \%$ buffered formaldehyde and embedded in paraffin for histological analysis.

\section{Semi-quantitative reverse transcription-polymerase chain reaction}

Total RNA was isolated from the lungs and heart using TRIzol reagent Invitrogen $^{\mathrm{TM}}$, Life Technologies, Thermo Fisher Scientific, Carlsbad, CA, USA). cDNA synthesis was performed with $3 \mu \mathrm{g}$ of total RNA according to the manufacturer's instructions (SuperScript II, Invitrogen ${ }^{\mathrm{TM}}$, Life Technologies, Thermo Fisher Scientific, Carlsbad, CA, USA). Specific oligonucleotides were designed for each gene (Table 4) using GeneRunner software, and we confirmed their amplification using Primer-BLAST [http:// www.ncbi.nlm.nih.gov/tools/primer-blast/]. We chose three RAAS genes (At1r, At2r and Ace) and three KKS genes (B1r, B2r and Klk-1) on the basis of their roles as the effectors and mediators of the metabolism of the active peptides. To evaluate heart gene reprogramming, we evaluated the mRNA levels of Acta1 and Col3a1. We used $18 S$ and Gapdh as housekeeping genes. After PCR amplification, the PCR products were loaded and subjected to electrophoresis in $1.5 \%$ agarose gels, stained with ethidium bromide and photodocumented in a transilluminator (UVP EC3 imaging system, UVP Inc., Upland, CA, USA). Densitometry was performed with the software Image J (National Institutes of Health, USA).

\section{Western blot}

To obtain the total protein, the lung samples were homogenized with Nonidet-P40 buffer (150 mM NaCl, 1 \% NP40, $50 \mathrm{mM}$ Tris- $\mathrm{HCl}, \mathrm{pH} 8.0$, and protease inhibitors) and centrifuged at $10,000 \mathrm{rpm} 4{ }^{\circ} \mathrm{C}$. The supernatant was collected and stored at $-70{ }^{\circ} \mathrm{C}$ until use.

Nuclear and non-nuclear cell fractions were obtained following the Abcam protocol. Briefly, the tissue was homogenized with cytoplasmic buffer (250 mM sucrose, $20 \mathrm{mM}$ HEPES pH 7.4, $10 \mathrm{mM} \mathrm{KCl,} 1.5 \mathrm{mM} \mathrm{MgCl}_{2}$, $1 \mathrm{mM}$ EDTA, $1 \mathrm{mM}$ EGTA, $1 \mathrm{mM}$ DTT). The homogenate was centrifuged at $3000 \mathrm{rpm}$ for $5 \mathrm{~min}$, and the 
Table 4 Oligonucleotides used for PCR amplification. The gene name, the sequence of forward (Fw) and reverse (Rv) oligonucleotide, the PCR product and the Genbank ID are shown

\begin{tabular}{|c|c|c|c|}
\hline Gen & Olinucleotides & PCR product $(\mathrm{pb})$ & Genbank ID \\
\hline \multirow[t]{2}{*}{ At1r } & Fw 5'-AATATTTGGAAACAGCTTGGT-3' & 331 & [GenBank: NM_030985] \\
\hline & Rv 5'-ATGATGATGCAGGTGACTTTG-3' & & \\
\hline \multirow[t]{2}{*}{ At2r } & FW 5'-TAGTTCCCCTTGTTTGGTG-3' & 428 & [GenBank: NM_012494] \\
\hline & Rv 5'-GAGGATGGCAAAAGGAAGT-3' & & \\
\hline \multirow[t]{2}{*}{ Ace } & FW 5'-CCAACAAGACTGCCACCTG-3' & 457 & [GenBank: NM_012544] \\
\hline & Rv 5'-GTACTGGTGACATCGAGGTTG-3' & & \\
\hline \multirow[t]{2}{*}{ Bir } & FW 5'-AGCATCTTCCTGGTGGTGG-3' & 420 & [GenBank: NM_030851] \\
\hline & Rv 5'-CCAGCAGACCAGGAAGGAG-3' & & \\
\hline \multirow[t]{2}{*}{$B 2 r$} & Fw 5'-GAGATCTACCTGGGCAACCT-3' & 599 & [GenBank: NM_173100] \\
\hline & Rv 5'-AGGAAGGTGCTGATCTGGAA-3' & & \\
\hline \multirow[t]{2}{*}{ Klk-1 } & FW 5'-CCCTCACCCTGACTTCAAC-3' & 236 & [GenBank: 001005382] \\
\hline & RV 5'-TCACACACTGGAGCTCATC-3' & & \\
\hline \multirow[t]{2}{*}{ Actal } & Fw 5'-ACATCGACATCAGGAAGGAC-3' & 234 & [GenBank: NM_019212] \\
\hline & RV 5'-CGTCGTACTCCTGCTTGGT-3' & & \\
\hline \multirow[t]{2}{*}{ Col3ar } & Fw 5'-AGGGTGATCGTGGTGAAAA-3' & 239 & [GenBank: NM_032085] \\
\hline & Rv 5'-TCCTCGATGTCCTITGATG-3' & & \\
\hline \multirow[t]{2}{*}{185} & Fw 5'-GCAGCTAGGAATAATGGAATA-3' & 188 & [GenBank: NR_046237] \\
\hline & Rv 5'-GACTTTCGTTCTTGATTAATGA-3' & & \\
\hline \multirow[t]{2}{*}{ Gapdh } & FW 5'-ACCACAGTCCATGCCATCAC-3' & 166 & [GenBank: NM_017008] \\
\hline & Rv 5'-TGCCAGTGAGCTTCCCGTT-3' & & \\
\hline
\end{tabular}

supernatant (non-nuclear fraction) was removed. The nuclear pellet was dispersed with a pipette, and then the first step was repeated to remove cytosolic contaminants from the pellet. The nuclear pellet was resuspended in the nuclear buffer (cytoplasmic buffer with $10 \%$ glycerol and $0.1 \%$ SDS). Finally, the nuclear pellet was sonicated on ice and centrifuged at $10,000 \mathrm{rpm}$, and the supernatant was removed and stored at $-70{ }^{\circ} \mathrm{C}$. The protein concentrations were determined using Bradford protein assay. A $6 \times$ Laemmli buffer was added to $30 \mu \mathrm{g}$ of protein, and the sample was loaded in $12 \%$ SDS-polyacrylamide gel and transferred to a PVDF membrane.

The membranes were blocked for $1 \mathrm{~h}$ with $5 \%$ of notfat milk. The membranes were then incubated overnight with primary antibodies to $\mathrm{AT}_{1} \mathrm{R}$ (1:600, rabbit polyclonal AT1 306 antibody, Sc-579), ACE (1:1000; goat polyclonal ACE N-20 antibody, Sc-12184), HO-1 (1:500, rabbit polyclonal HO-1 H-105 antibody, Sc-10789) and $\gamma$-GCSc $(1: 600$, rabbit polyclonal $\gamma$-GCSc H-338 antibody, Sc-22755) all from Santa Cruz Biotechnology (Delaware Ave, Santa Cruz, CA, USA). HRP-conjugated secondary antibodies (Bio-Rad laboratories, Hercules, CA, USA) were incubated $1 \mathrm{~h}$ at a dilution of 1:10,000. Immunoreactivity was detected using ECL western blotting detection reagents (GE health care, Buckinghamshire HP7 9NA, $\mathrm{UK})$. The bands were visualized by exposure to $\mathrm{x}$-ray film.
The $x$-ray film was photodocumented with a UVP (UVP EC3 imaging system, UVP Inc., USA). We used $\alpha$-actin (donated by Dr. Hernández- Hernández, CINVESTAVIPN) as an internal control to correct for protein loading. For the subcellular fractions, we used GAPDH (1:1000, mouse monoclonal GAPDH 6C5 antibody, Sc-32,233) and acetyl-Histone-4 (1:1000, mouse monoclonal Ac-Histone H4 Ser 1/Lys 5/Lys 8/Lys 12 antibody, Sc-34,263) to confirm the purity of the fractions.

\section{$\left[{ }^{3} \mathrm{H}\right]$-Angiotensin-Il binding to lung cell membranes}

The lung tissue samples were placed in $10 \mathrm{ml}$ of lysis buffer (10 mM Tris-HCl, $1 \mathrm{mM}$ EGTA, pH 7.4 at $\left.4{ }^{\circ} \mathrm{C}\right)$ and homogenized with a Polytron (3 cycles, $5 \mathrm{~s}$ each). The homogenate was centrifuged $\left(1,000 \times g, 10 \mathrm{~min}, 4^{\circ} \mathrm{C}\right)$, the pellet was discarded and the supernatant was centrifuged at $42,000 \times g\left(20 \mathrm{~min}, 4{ }^{\circ} \mathrm{C}\right)$. The resulting pellet was resuspended in lysis buffer and centrifuged again $(42,000 \times g$, $20 \mathrm{~min}, 4^{\circ} \mathrm{C}$ ). The pellet (membranes) was resuspended in incubation buffer $\left(20 \mathrm{mM}\right.$ Tris- $\mathrm{HCl}, 5 \mathrm{mM} \mathrm{MgCl}_{2}$, $100 \mathrm{mM} \mathrm{NaCl}, 2 \mathrm{mg} / \mathrm{ml}$ bovine serum albumin (BSA); $\mathrm{pH} 7.4$ at $4{ }^{\circ} \mathrm{C}$ ), and the suspension was immediately used in binding assays. The protein contents were determined by the Bradford assay, using BSA as standard.

Saturation analysis was carried out in $100 \mu \mathrm{l}$ of incubation buffer containing [Tyrosil-3,5- ${ }^{3} \mathrm{H}(\mathrm{N})$ ]-Angiotensin-II 
(ARC inc., Saint Louis, MO, USA) $(0.5-40 \mathrm{nM})$ and $~ 40 \mu \mathrm{g}$ protein. For single-point experiments, the incubations contained $10 \mathrm{nM}\left[{ }^{3} \mathrm{H}\right]$-Angiotensin-II. The samples were equilibrated for $60 \mathrm{~min}$ at $25{ }^{\circ} \mathrm{C}$ in a water bath with continuous gentle rocking, and the incubations were terminated by filtration through Whatman GF/B glass fiber paper, pre-soaked in $0.3 \%$ polyethylenimine. Non-specific binding was determined as the binding insensitive to $100 \mu \mathrm{M}$ of the antagonist telmisartan (Sigma Aldrich, USA). The filters were washed 3 times with $1 \mathrm{ml}$ ice-cold Tris- $\mathrm{HCl}$ buffer ( $20 \mathrm{mM}, \mathrm{pH} 7.4)$, soaked in $3 \mathrm{ml}$ scintillator, and the tritium content was determined by liquid scintillation spectroscopy (Multi-purpose Scintillation Counter, Beckman LS-6500). The saturation binding data were fit with a hyperbolic function using non-linear regression with GraphPad Prism 5 (Graph Pad Software, San Diego, CA, USA).

\section{Histology}

Slides of $5 \mu \mathrm{m}$ sections of the heart tissues were stained with Hematoxylin/Eosin stain. We photographed all of the intramyocardial coronary arteries observed in the slides (two slides from each tissue sample). We performed a blinded analysis of the measure of the thickness using Image J. Twenty radial measurements for each artery from the intima to the adventitia wall were registered. For the statistical analysis we used the median of each artery; we included in the analysis between 15 to 25 arteries per group. Semi-quantitative analysis of mononuclear cells in heart tissue was performed counting the number of fields with mononuclear cells per slide.

\section{Statistical analysis}

All statistical analyses were performed using SigmaPlot version 11.0. We performed descriptive statistical analyses. To compare the four groups, we performed KruskalWallis test, considering non-normal data distribution. Student Newman-Keul's post-hoc test was used for all pair-wise comparisons. We considered the differences to be statistically significant when $P \leq 0.05$. All comparisons were performed with respect to filtered air as the control group.

\section{Competing interest}

The authors declare that they have no competing interests.

\begin{abstract}
Authors' contributions
OGAA proposed the molecular targets, carried out the molecular biology, the binding assay, analyzed the data and wrote the manuscript. TMUR participated in the animal exposure and Western blot analyses. JAAM supervised the binding assay and data analysis. OB participated in the data analysis and study supervision. ADVR devised and developed the animal exposure, carried out its design and coordination, and supervised the draft of the manuscript. All authors read and approved the final manuscript.
\end{abstract}

\section{Acknowledgement}

This work was funded by Conacyt [Consejo Nacional de Ciencia y Tecnología] Grant No. 57752 and 167778.

\section{Author details}

'Departamento de Toxicología, Centro de Investigación y de Estudios Avanzados del Instituto Politécnico Nacional, Avenida Instituto Politécnico Nacional, 2508, México D. F., CP. 07360, Mexico. ²Departamento de Fisiología, Neurociencias y Biofísica, Centro de Investigación y de Estudios Avanzados del Instituto Politécnico Nacional, Avenida Instituto Politécnico Nacional, 2508, México D. F., C.P. 07360, Mexico.

Received: 23 October 2014 Accepted: 15 June 2015

Published online: 26 June 2015

\section{References}

1. Pope III CA, Dockery DW. Health effects of fine particulate air pollution: lines that connect. J Air Waste Manage Assoc. 2006;56:709-42.

2. Simkhovich BZ, Kleinman MT, Kloner RA. Air pollution and cardiovascular injury: epidemiology, toxicology, and mechanisms. J Am Coll Cardiol. 2008:52:719-26.

3. Pope CA, Burnett RT, Thurston GD, Thun MJ, Calle EE, Krewski D, et al. Cardiovascular mortality and long-term exposure to particulate air pollution epidemiological evidence of general pathophysiological pathways of disease. Circulation. 2004;109:71-7.

4. Donaldson K, Stone V, Seaton A, MacNee W. Ambient particle inhalation and the cardiovascular system: potential mechanisms. Environ Health Perspect. 2001;109:523.

5. Mutlu GM, Green D, Bellmeyer A, Baker CM, Burgess Z, Rajamannan N, et al. Ambient particulate matter accelerates coagulation via an IL-6-dependent pathway. J Clin Invest. 2007;117:2952-61.

6. Rhoden CR, Wellenius GA, Ghelfi E, Lawrence J, González-Flecha B. PM-induced cardiac oxidative stress and dysfunction are mediated by autonomic stimulation. Biochim Biophys Acta Gen Subj. 2005;1725:305-13.

7. Sharma JN. Role of tissue kallikrein-kininogen-kinin pathways in the cardiovascular system. Arch Med Res. 2006;37:299-306.

8. Kuhr F, Lowry J, Zhang Y, Brovkovych V, Skidgel R. Differential regulation of inducible and endothelial nitric oxide synthase by kinin B1 and B2 receptors. Neuropeptides. 2010;44:145-54.

9. Thomas WG, Mendelsohn FA. Angiotensin receptors: form and function and distribution. Int J Biochem Cell Biol. 2003;35:774-9.

10. Lavoie JL, Sigmund CD. Minireview: overview of the renin-angiotensin system -an endocrine and paracrine system. Endocrinology. 2003;144:2179-83.

11. Iwai M, Horiuchi M. Devil and angel in the renin-angiotensin system: ACE-angiotensin II-AT1 receptor axis vs. ACE2-angiotensin-(1-7)-Mas receptor axis. Hypertens Res. 2009;32:533-6.

12. Tsutsumi Y, Matsubara H, Masaki H, Kurihara H, Murasawa S, Takai S, et al. Angiotensin II type 2 receptor overexpression activates the vascular kinin system and causes vasodilation. J Clin Invest. 1999;104:925.

13. Bergaya $\mathrm{S}$, Hilgers RH, Meneton $\mathrm{P}$, Dong $\mathrm{Y}$, Bloch-Faure $\mathrm{M}$, Inagami $\mathrm{T}$, et al. Flow-dependent dilation mediated by endogenous kinins requires angiotensin AT2 receptors. Circ Res. 2004;94:1623-9.

14. Bhoola K, Figueroa C, Worthy K. Bioregulation of kinins: kallikreins, kininogens, and kininases. Pharmacol Rev. 1992;44:1-80.

15. Yousef GM, Diamandis EP. The New Human Tissue Kallikrein Gene Family: Structure, Function, and Association to Disease 1. Endocr Rev. 2001;22:184-204.

16. Rueckschloss U, Quinn MT, Holtz J, Morawietz H. Dose-dependent regulation of NAD (P) H oxidase expression by angiotensin II in human endothelial cells protective effect of angiotensin II type 1 receptor blockade in patients with coronary artery disease. Arterioscler Thromb Vasc Biol. 2002;22:1845-51.

17. Rajagopalan S, Kurz S, Münzel T, Tarpey M, Freeman BA, Griendling KK, et al. Angiotensin II-mediated hypertension in the rat increases vascular superoxide production via membrane NADH/NADPH oxidase activation. Contribution to alterations of vasomotor tone. J Clin Invest. 1996;97:1916.

18. Dias JP, Talbot S, Sénécal J, Carayon P, Couture R. Kinin B1 receptor enhances the oxidative stress in a rat model of insulin resistance: outcome in hypertension, allodynia and metabolic complications. PLoS One. 2010;5, e12622.

19. Ni A, Yin H, Agata J, Yang Z, Chao L, Chao J. Overexpression of kinin B1 receptors induces hypertensive response to des-Arg9-bradykinin and susceptibility to inflammation. J Biol Chem. 2003;278:219-25.

20. Morand-Contant M, Anand-Srivastava MB, Couture R. Kinin B1 receptor upregulation by angiotensin II and endothelin-1 in rat vascular smooth muscle cells: receptors and mechanisms. Am J Physiol Heart Circ Physiol. 2010;299:H1625-32. 
21. Kintsurashvili E, Duka I, Gavras I, Johns C, Farmakiotis D, Gavras H. Effects of ANG II on bradykinin receptor gene expression in cardiomyocytes and vascular smooth muscle cells. Am J Physiol Heart Circ Physiol. 2001;281:H1778-83.

22. Harrison-Bernard LM, El-Dahr SS, O'Leary DF, Navar LG. Regulation of angiotensin II type 1 receptor mRNA and protein in angiotensin II-induced hypertension. Hypertension. 1999;33:340-6.

23. Gurantz D, Cowling RT, Villarreal FJ, Greenberg BH. Tumor necrosis factor-a upregulates angiotensin II type 1 receptors on cardiac fibroblasts. Circ Res. 1999:85:272-9.

24. Wassmann S, Stumpf M, Strehlow K, Schmid A, Schieffer B, Böhm M, et al. Interleukin-6 induces oxidative stress and endothelial dysfunction by overexpression of the angiotensin II type 1 receptor. Circ Res. 2004;94:534-41.

25. Sasamura H, Nakazato $Y$, Hayashida T, Kitamura Y, Hayashi M, Saruta T. Regulation of vascular type 1 angiotensin receptors by cytokines. Hypertension. 1997;30:35-41.

26. Kranzhöfer R, Schmidt J, Pfeiffer CA, Hagl S, Libby P, Kübler W. Angiotensin induces inflammatory activation of human vascular smooth muscle cells. Arterioscler Thromb Vasc Biol. 1999;19:1623-9.

27. Tiffany CW, Burch RM. Bradykinin stimulates tumor necrosis factor and interleukin-1 release from macrophages. FEBS Lett. 1989;247:189-92.

28. Hayashi R, Yamashita N, Matsui S, Fujita T, Araya J, Sassa K, et al. Bradykinin stimulates IL-6 and IL-8 production by human lung fibroblasts through ERK-and p38 MAPK-dependent mechanisms. Eur Respir J. 2000;16:452-8.

29. Yayama K, Okamoto $\mathrm{H}$. Angiotensin I-induced vasodilation via type 2 receptor: Role of bradykinin and nitric oxide. Int Immunopharmacol. 2008;8:312-8.

30. Brasier AR, Recinos A, Eledrisi MS. Vascular inflammation and the renin-angiotensin system. Arterioscler Thromb Vasc Biol. 2002;22:1257-66.

31. Kaplan AP, Joseph K, Silverberg M. Pathways for bradykinin formation and inflammatory disease. J allergy clin immunol. 2002;109:195-209.

32. Dielis AW, Smid M, Spronk HM, Hamulyak K, Kroon AA, ten Cate H, et al. The Prothrombotic Paradox of Hypertension Role of the Renin-Angiotensin and Kallikrein-Kinin Systems. Hypertension. 2005;46:1236-42.

33. Remková A, Remko M. The role of renin-angiotensin system in prothrombotic state in essential hypertension. Physiol Res. 2010;59.

34. Campbell D. Towards understanding the kallikrein-kinin system: insights from measurement of kinin peptides. Braz J Med Biol Res. 2000;33:665-77.

35. Su JB. Different cross-talk sites between the renin-angiotensin and the kallikreinkinin systems. J Renin-Angiotensin-Aldosterone Syst. 2013;1470320312474854.

36. Schmaier $\mathrm{AH}$. The kallikrein-kinin and the renin-angiotensin systems have a multilayered interaction. Am J Physiol Regul, Integr Comp Physiol. 2003;285:R1-R13.

37. Gillis C. Metabolism of vasoactive hormones by lung. Anesthesiology. 1973;39:626-32.

38. Zhang L, Wang H, Xiao Y, Cai Y, Ren J. Early lung injury contributes to lung fibrosis via AT1 receptor in rats. Acta Pharmacol Sin. 2007;28:227-37.

39. Myou S, Fujimura M, Kamio $Y$, Ishiura $Y$, Kurashima $K$, Tachibana H, et al. Effect of losartan, a type 1 angiotensin II receptor antagonist, on bronchial hyperresponsiveness to methacholine in patients with bronchial asthma. Am J Respir Crit Care Med. 2000;162:40-4.

40. Ulrich MM, Alink GM, Kumarathasan P, Vincent R, Boere AJF, Cassee FR. Health effects and time course of particulate matter on the cardiopulmonary system in rats with lung inflammation. J Toxicol Environ Health A. 2002;65:1571-95.

41. Gunnison A, Chen LC. Effects of subchronic exposures to concentrated ambient particles in mice: VI. gene expression in heart and lung tissue. Inhal toxicol. 2005:17:225-33.

42. Li Z, Carter JD, Dailey LA, Huang Y-CT. Pollutant particles produce vasoconstriction and enhance MAPK signaling via angiotensin type receptor. Environ Health Perspect. 2005;113:1009.

43. Wold LE, Ying Z, Hutchinson KR, Velten M, Gorr MW, Velten C, et al. Cardiovascular remodeling in response to long-term exposure to fine particulate matter air pollution. Circ Heart Fail. 2012;5:452-61.

44. Ying Z, Yue $P, X u X$, Zhong M, Sun Q, Mikolaj M, et al. Air pollution and cardiac remodeling: a role for RhoA/Rho-kinase. Am JPhysiol Heart Circ Physiol. 2009;296:H1540.

45. Rosati AM, Traversa U. Mechanisms of inhibitory effects of zinc and cadmium ions on agonist binding to adenosine $\mathrm{A} 1$ receptors in rat brain. Biochem Pharmacol. 1999;58:623-32.

46. Hubbard PC, Lummis SC. $Z n<\sup >2+</$ sup $>$ enhancement of the recombinant $5-\mathrm{HT}<$ sub $>3</$ sub $>$ receptor is modulated by divalent cations. Eur J Pharmacol. 2000;394:189-97.
47. Marinissen MJ, Gutkind JS. G-protein-coupled receptors and signaling networks: emerging paradigms. Trends Pharmacol Sci. 2001;22:368-76.

48. Boivin B, Vaniotis G, Allen BG, Hebert TE. G protein-coupled receptors in and on the cell nucleus: a new signaling paradigm? J Recep Signal Transduction. 2008;28:15-28

49. Lu D, Yang H, Shaw G, Raizada MK. Angiotensin II-Induced Nuclear Targeting of the Angiotensin Type 1 (AT1) Receptor in Brain Neurons 1. Endocrinology. 1998;139:365-75.

50. Tadevosyan A, Maguy A, Villeneuve LR, Babin J, Bonnefoy A, Allen BG, et al. Nuclear-delimited angiotensin receptor-mediated signaling regulates cardiomyocyte gene expression. J Biol Chem. 2010;285:22338-49.

51. Figueroa CD, Marchant A, Novoa U, Förstermann U, Jarnagin K, Schölkens B, et al. Differential distribution of bradykinin B2 receptors in the rat and human cardiovascular system. Hypertension. 2001;37:110-20.

52. McEachern AE, Shelton ER, Bhakta S, Obernolte R, Bach C, Zuppan P, et al. Expression cloning of a rat B2 bradykinin receptor. Proc Natl Acad Sci. 1991;88:7724-8

53. Madeddu P, Emanueli C, Varoni MV, Demontis MP, Anania V, Gorioso N, et al. Regulation of bradykinin B2-receptor expression by oestrogen. $\mathrm{Br}$ J Pharmacol. 1997;121:1763-9.

54. Kim S, Iwao H. Molecular and cellular mechanisms of angiotensin IImediated cardiovascular and renal diseases. Pharmacol Rev. 2000;52:11-34

55. Paradis P, Dali-Youcef N, Paradis FW, Thibault G, Nemer M. Overexpression of angiotensin II type I receptor in cardiomyocytes induces cardiac hypertrophy and remodeling. Proc Natl Acad Sci. 2000;97:931-6.

56. Kim S, Ohta K, Hamaguchi A, Yukimura T, Miura K, Iwao H. Angiotensin II induces cardiac phenotypic modulation and remodeling in vivo in rats. Hypertension. 1995;25:1252-9.

57. Tsybouleva N, Zhang L, Chen S, Patel R, Lutucuta S, Nemoto S, et al. Aldosterone, through novel signaling proteins, is a fundamental molecular bridge between the genetic defect and the cardiac phenotype of hypertrophic cardiomyopathy. Circulation. 2004;109:1284-91.

58. Sano M, Fukuda K, Kodama H, Pan J, Saito M, Matsuzaki J, et al. Interleukin-6 family of cytokines mediate angiotensin II-induced cardiac hypertrophy in rodent cardiomyocytes. J Biol Chem. 2000;275:29717-23.

59. Schmid O, Möller W, Semmler-Behnke MA, Ferron G, Karg E, Lipka J, et al. Dosimetry and toxicology of inhaled ultrafine particles. Biomarkers. 2009;14:67-73.

60. Gould NS, Day BJ. Targeting maladaptive glutathione responses in lung disease. Biochem Pharmacol. 2011;81:187-93.

61. Cross CE, van der Vliet A, O'Neill CA, Louie S, Halliwell B. Oxidants, antioxidants, and respiratory tract lining fluids. Environ Health Perspect. 1994;102:185.

62. Otterbein LE, Choi AM. Heme oxygenase: colors of defense against cellular stress. Am J PhysioLung Cell Mol Physiol. 2000;279:L1029-37.

63. Abraham NG, Kappas A. Heme oxygenase and the cardiovascular-renal system. Free Radic Biolo Med. 2005;39:1-25.

64. Ryter SW, Otterbein LE, Morse D, Choi AM. Heme oxygenase/carbon monoxide signaling path-ways: Regulation and functional significance. In Oxygen/Nitrogen Radicals: Cell Injury and Disease. Springer; 2002. p. 249-63.

65. Idriss NK, Blann AD, Lip GY. Hemoxygenase-1 in cardiovascular disease. J Am Coll Cardiol. 2008:52:971-8.

66. Fredenburgh LE, Perrella MA, Mitsialis SA. The role of heme oxygenase-1 in pulmonary disease. Am J Respir Cell Mol Biol. 2007;36:158-65.

67. Ishizaka N, Griendling KK. Heme oxygenase-1 is regulated by angiotensin II in rat vascular smooth muscle cells. Hypertension. 1997;29:790-5.

68. Li N, Wang M, Oberley TD, Sempf JM, Nel AE. Comparison of the pro-oxidative and proinflammatory effects of organic diesel exhaust particle chemicals in bronchial epithelial cells and macrophages. Jlmmunol. 2002:169:4531-41.

69. Danielsen PH, Møller $\mathrm{P}$, Jensen KA, Sharma AK, Wallin H, Bossi R, et al. Oxidative stress, DNA damage, and inflammation induced by ambient air and wood smoke particulate matter in human A549 and THP-1 cell lines. Chem Res Toxicol. 2011;24:168-84.

70. Li N, Sioutas C, Cho A, Schmitz D, Misra C, Sempf J, et al. Ultrafine particulate pollutants induce oxidative stress and mitochondrial damage. Environ Health Perspect. 2003;111:455.

71. Sugimoto R, Kumagai Y, Nakai Y, Ishii T. 9, 10-Phenanthraquinone in diesel exhaust particles downregulates $\mathrm{Cu}, \mathrm{Zn}-\mathrm{SOD}$ and $\mathrm{HO}-1$ in human pulmonary epithelial cells: Intracellular iron scavenger 1, 10-phenanthroline affords protection against apoptosis. Free Radic Biol Med. 2005:38:388-95. 
72. Suzuki M, Betsuyaku T, Ito Y, Nagai K, Nasuhara Y, Kaga K, et al. Down-regulated NF-E2-related factor 2 in pulmonary macrophages of aged smokers and patients with chronic obstructive pulmonary disease. Am J Respir Cell Mol Biol. 2008:39:673-82.

73. Yamada N, Yamaya M, Okinaga S, Nakayama K, Sekizawa K, Shibahara S, et al. Microsatellite polymorphism in the heme oxygenase-1 gene promoter is associated with susceptibility to emphysema. Am J Hum Genet. 2000:66:187-95.

74. Kaneda H, Ohno M, Taguchi J, Togo M, Hashimoto H, Ogasawara K, et al. Heme oxygenase-1 gene promoter polymorphism is associated with coronary artery disease in Japanese patients with coronary risk factors. Arterioscler Thromb Vasc Biol. 2002:22:1680-5.

75. Li H-J, Yin H, Yao Y-Y, Shen B, Bader M, Chao L, et al. Tissue kallikrein protects against pressure overload-induced cardiac hypertrophy through kinin B2 receptor and glycogen synthase kinase-3 $\beta$ activation. Cardiovasc Res. 2007;73:130-42

76. Meneton P, Bloch-Faure M, Hagege AA, Ruetten H, Huang W, Bergaya S, et al. Cardiovascular abnormalities with normal blood pressure in tissue kallikrein-deficient mice. Proc Natl Acad Sci. 2001;98:2634-9.

77. Borgoño CA, Diamandis EP. The emerging roles of human tissue kallikreins in cancer. Nat Rev Cancer. 2004:4:876-90.

78. Christiansen SC, Proud D, Sarnoff RB, Juergens U, Cochrane CG, Zuraw BL. Elevation of tissue kallikrein and kinin in the airways of asthmatic subjects after endobronchial allergen challenge. Am Rev Respir Dis. 1992;145:900-5.

79. Sexton D, Chen T, Martik D, Kuzmic P, Kuang G, Chen J, et al. Specific inhibition of tissue kallikrein 1 with a human monoclonal antibody reveals a potential role in airway diseases. Biochem J. 2009;422:383-92.

80. Takimoto M, Mitani H, Hori S, Kimura M, Bandoh T, Okada T. Expression, secretion, and inhibition of angiotensin-converting enzyme in cultured human bronchial epithelial cells. Eur J Pharmacol. 1999;370:169-77.

81. Kohlstedt K, Gershome C, Friedrich M, Muller-Esterl W, Alhenc-Gelas F, Busse $R$, et al. Angiotensin-converting enzyme (ACE) dimerization is the initial step in the ACE inhibitor-induced ACE signaling cascade in endothelial cells. Mol Pharmacol. 2006;69:1725-32.

82. Kohlstedt K, Shoghi F, Müller-Esterl W, Busse R, Fleming I. CK2 phosphorylates the angiotensin-converting enzyme and regulates its retention in the endothelial cell plasma membrane. Circ Res. 2002;91:749-56.

83. Kohlstedt K, Busse R, Fleming I. Signaling via the angiotensin-converting enzyme enhances the expression of cyclooxygenase-2 in endothelial cells. Hypertension. 2005;45:126-32.

84. Mori Y, Matsubara H, Murasawa S, Kijima K, Maruyama K, Tsukaguchi H, et al. Translational regulation of angiotensin II type $1 \mathrm{~A}$ receptor role of upstream AUG triplets. Hypertension. 1996;28:810-7.

85. Guerra R, Vera-Aguilar E, Uribe-Ramirez M, Gookin G, Camacho J, Osornio-Vargas $A$, et al. Exposure to inhaled particulate matter activates early markers of oxidative stress, inflammation and unfolded protein response in rat striatum. Toxicol Lett. 2013;222:146-54.

86. Kodavanti UP, Schladweiler MC, Gilmour PS, Wallenborn JG, Mandavilli BS, Ledbetter AD, et al. The role of particulate matter-associated zinc in cardiac injury in rats. Environ Health Perspect. 2008;13-20.

87. Hughes LS, Cass GR, Gone J, Ames M, Olmez I. Physical and chemical characterization of atmospheric ultrafine particles in the Los Angeles area. Environ Sci Technol. 1998;32:1153-61.

88. Utsunomiya S, Jensen KA, Keeler GJ, Ewing RC. Direct identification of trace metals in fine and ultrafine particles in the Detroit urban atmosphere. Environ Sci Technol. 2004;38:2289-97.

89. Lin C-C, Chen S-J, Huang K-L, Hwang W-I, Chang-Chien G-P, Lin W-Y. Characteristics of metals in nano/ultrafine/fine/coarse particles collected beside a heavily trafficked road. Environ Sci Technol. 2005;39:8113-22.

90. Barnes PJ. The cytokine network in asthma and chronic obstructive pulmonary disease. J Clin Invest. 2008;118:3546-56.

91. Camoretti-Mercado B, Solway J. Transforming growth factor- $\beta 1$ and disorders of the lung. Cell Biochem Biophys. 2005:43:131-48.

92. Rosenkranz S. TGF- $\beta 1$ and angiotensin networking in cardiac remodeling Cardiovasc Res. 2004;63:423-32.

93. Zou Y, Akazawa H, Qin Y, Sano M, Takano H, Minamino T, et al. Mechanical stress activates angiotensin II type 1 receptor without the involvement of angiotensin II. Nat Cell Biol. 2004;6:499-506.
94. Malhotra R, Sadoshima J, Brosius FC, Izumo S. Mechanical stretch and angiotensin II differentially upregulate the renin-angiotensin system in cardiac myocytes in vitro. Circ Res. 1999;85:137-46.

95. De Vizcaya-Ruiz A, Gutiérrez-Castillo M, Uribe-Ramirez M, Cebrián M, Mugica-Alvarez V, Sepúlveda J, et al. Characterization and in vitro biological effects of concentrated particulate matter from Mexico City. Atmos Environ. 2006;40:583-92.

\section{Submit your next manuscript to BioMed Central and take full advantage of:}

- Convenient online submission

- Thorough peer review

- No space constraints or color figure charges

- Immediate publication on acceptance

- Inclusion in PubMed, CAS, Scopus and Google Scholar

- Research which is freely available for redistribution 